\title{
Comparative morphological study of the Neotropical Cleomenini genera and their transference to the tribes Rhopalophorini Blanchard and Rhinotragini Thomson (Coleoptera, Cerambycidae, Cerambycinae) ${ }^{1}$
}

\author{
José Ricardo M. Mermudes² \& Dilma Solange Napp
}

${ }^{1}$ Contribution $\mathrm{n}^{\circ} 1458$ of the Departamento de Zoologia, Universidade Federal do Paraná.

${ }^{2}$ Museu de Zoologia, Universidade de São Paulo. Caixa Postal 45494, 04218-970 São Paulo-SP, Brazil. Fellowship of FAPESP.

${ }^{3}$ Departamento de Zoologia, Universidade Federal do Paraná. Caixa Postal 19020, 81531-980 Curitiba-PR, BRAZIL. Fellowship of CNPq.

\begin{abstract}
In order to investigate the affinities of the hitherto considered Neotropical Cleomenini genera, a detailed morphological comparative study was carried out based on representatives of their type species and other congeneric species. The results, when compared with representatives of Cleomenes Thomson and other non Neotropical Cleomenini genera together with representatives of Rhopalophorini Blanchard and Rhinotragini Thomson, show that: 1) Listroptera Audinet-Serville, 1834, Dihammaphora Chevrolat, 1859, Haenkea Tippmann, 1953, Aguassay Napp \& Mermudes, 2001 and Timabiara Napp \& Mermudes, 2001 form a very homogeneous group, not related to other Cleomenini, but sharing several synapomorphies with the Rhopalophorini; therefore they are herein transferred to this tribe; 2) the affinities of Dihammaphoroides Zajciw, 1967, were not clearly defined, needing further investigations; nevertheless, the genus is tentatively included in Rhopalophorini due to its morphological similarity with Dihammaphora and allied genera; 3) Pandrosos Bates, 1867 is brought back to Rhinotragini, in which it was originally placed. Therefore, the tribe Cleomenini Lacordaire is no longer represented in the New World.
\end{abstract}

KeYwords. Cleomenini; morphology; Rhinotragini; Rhopalophorini; taxonomy.

Resumo. Estudo morfológico comparado dos gêneros neotropicais de Cleomenini e sua transferência para as tribos Rhopalophorini Blanchard e Rhinotragini Thomson (Coleoptera, Cerambycidae, Cerambycinae). Com o objetivo de esclarecer as afinidades dos atuais gêneros neotropicais de Cleomenini, foi feito um estudo detalhado da morfologia de representantes das espécies-tipo e/ou de espécies congenéricas. Para efeitos de comparação, foram estudados representantes de Cleomenes Thomson e de outro gêneros não neotropicais de Cleomenini, além de representantes de Rhopalophorini Blanchard e de Rhinotragini Thomson. Os resultados evidenciaram: 1) Listroptera Audinet-Serville, 1834, Dihammaphora Chevrolat, 1859, Haenkea Tippmann, 1953, Aguassay Napp \& Mermudes, 2001 e Timabiara Napp \& Mermudes, 2001 formam um grupo muito homogêneo e que compartilha várias sinapomorfias com Rhopalophorini, não tendo nenhuma afinidade com Cleomenini; por essa razão, são aqui transferidos para aquela tribo; 2) embora as afinidades de Dihammaphoroides Zajciw, 1967 não tenham ficado bem definidas, o gênero é, provisoriamente, incluído em Rhopalophorini por sua semelhança com Dihammaphora e gêneros afins; 3) Pandrosos Bates, 1867 é transferido para Rhinotragini, tribo em que foi originalmente descrito. Assim, a tribo Cleomenini Lacordaire não é mais representada nas Américas.

Palavras-Chave. Cleomenini; morfologia; Rhinotragini; Rhopalophorini; taxonomia.

Cleomenini Lacordaire, 1869 comprises 27 genera: 12, including the type genus Cleomenes Thomson, 1864, are primarily Oriental; eight are Afrotropical and one described from Australia (AurivilLius 1912; GressitT 1951; GressitT \& Rondon 1970). In the New World, Monné (1993) catalogued seven South American genera: Listroptera Audinet-Serville, 1834, Dihammaphora Chevrolat, 1859, Pandrosos Bates, 1867, Eupempelus Bates, 1870, Fregolia Gounelle, 1911, Haenkea Tippmann, 1953, and Dihammaphoroides Zajciw, 1967. Except Dihammaphora with 36 species (MonNé 1993; Mermudes 1998), the other Neotropical genera are monotypic or with only two or three species. Their immatures are unknown and the hosts recorded for only two of the Neotropical species (DI Iorio 1994; TAVAKILIAN et al. 1997; Di IoRio 1997; MonnÉ 2000).

LACORDAIRE (1869), in establishing Cleomenini, recognized its great similarity with Rhopalophorini Blanchard, 1845, emphasizing that the two tribes may barely be distinguished by the length of the antennae and shape of the antennal segments. Only two Neotropical genera were included (Listroptera and Dihammaphora) and, according to LACORDAIRE (l.c.), they easily differentiated from the others by both elytral shape and legs.

Rhopalophorini Blanchard, 1845 is primarily Neotropical and currently comprises 28 genera, of which 24 were described from and occurring almost exclusively in the Neotropics (Aurivillius 1912; Giesbert \& CHEMSAK 1993; Monné 1994; MARQues \& NAPP 2003).

Through the literature, it can be observed that most of the Neotropical Cleomenini have always been related to the Rhopalophorini, while the tribal assignment of some of the genera was doubtful since their original description (see Literature Review and also Mermudes \& NAPP 2001). Also, the maintenance of Cleomenini and Rhopalophorini as distinct tribes and the affinities of the Neotropical genera have been 
questioned, respectively, by Fragoso (1985) and Marques (1998).

An attempt to discover the affinities of the Neotropical Cleomenini has been made by Mermudes (1999) who found that the Neotropical genera were neither related to Cleomenes nor to other genera of Cleomenini. He noticed, however, that most of them formed a very homogeneous group having more affinities with Rhopalophora Audinet-Serville, 1834; on the other hand, some other genera should be removed to other tribes. Following Mermudes (1999), Eupempelus was transferred to Heteropsini Lacordaire, 1869 and Fregolia, to Callidiopini Lacordaire, 1869 (MermudEs \& NAPP 2001, 2002).

Continuing the study of the Neotropical Cleomenini, the morphology of the genera Dihammaphora, Listroptera, Haenkea, Dihammaphoroides, Pandrosos, Aguassay Napp \& Mermudes, 2001 and Timabiara Napp \& Mermudes, 2001 is presented herein and discussed in comparison with those of Rhopalophora Audinet-Serville, 1834 and Cleomenes in addition to other Rhopalophorini and Cleomenini genera. Also, the morphology of Rhinotragus dorsiger (Germar, 1824) (Rhinotragini) was studied in order to investigate the affinities of Pandrosos that was originally included in this tribe (BATES 1867)

The results strongly support the transference of Listroptera Audinet-Serville, Dihammaphora Chevolat, Haenkea Tippmann, Aguassay Napp \& Mermudes and Timabiara Napp \& Mermudes from Cleomenini to Rhopalophorini; similarly, Pandrosos Bates is transferred to Rhinotragini Lacordaire. Dihammaphoroides Zajciw is tentatively referred to Rhopalophorini.

\section{LITERATUREREVIEW}

Listroptera was proposed by AudinEt-ServiLle (1834) based on a single species, Callidium tenebrosum Fabricius, 1792 and placed in the group having the prothorax rounded at the sides and impressed dorsally. Rhopalophora AudinetServille, 1834 was included among genera with a cylindrical, elongate prothorax.

Chevrolat (1859) established Dihammaphora for ten species originally described in Rhopalophora, relating both genera to Listroptera.

ThOMson (1860) included Listroptera and Dihammaphora in the $11^{\text {th }}$ Division, Rhopalophoritae Verae (Group Rhopalophoritae) along with Rhopalophora and other current Rhopalophorini genera. In 1864, he placed Listroptera, Dihammaphora and several Rhopalophorini genera (e.g. Rhopalophora, Closteropus Guérin-Meneville, 1844, Cosmisoma Audinet-Serville, 1834) in his group "Callichromitae Vera", division Pseudolepturitae.

LACORDAIRE (1869) established Cleomenini for 14 genera: seven from the Oriental Region, four from Africa, one from Australia and two from South America (Listroptera and Dihammaphora). He noticed the heterogeneity of the group and considered this was probably due to the worldwide distribution of the tribe, so the particular facies of each group of genera was in accordance with the region in which they were distributed.

Pandrosos was proposed by BATEs (1867) for a single species - Rhinotragus exilis White, 1855 - and was originally placed in Rhinotragini near Rhinotragus Germar, 1824 and Oregostoma Audinet-Serville, 1833. It was kept in this tribe by LACORDAire (1869) and Bates (1870). Subsequently, Bates (1873) transferred Pandrosos to Compsocerini Thomson, 1864 relating it to Coremia Audinet-Serville, 1834, presently included in Rhopalophorini (MARQues \& NAPP 1996). Finally, Pandrosos was transferred to Cleomenini by Gounelle (1911) who established the synonymy of Rhinotragus exilis White, 1855 (type species of Pandrosos) with Cerambyx phtisicus Klug, 1825 and placed the genus near Listroptera.

Aurivillius (1912) catalogued 21 genera from the Australian, Oriental, Afrotropical and Neotropical regions and BLACKWELDER (1946), five American genera.

SaAlas (1936) noticed the similarity between the wing venation of the examined Rhopalophorini [Rhopalophora axillaris (Klug, 1825), now Gurubira, and Ornithia mexicana Sturm, 1843, now in Dryobiini] and Cleomenini (Apiogaster rufiventris Perroud, 1855 and Listroptera aterrima Germar, 1839), placing the latter into a more specialized lineage.

Tippmann (1953) proposed Haenkea to include a single species, H. zishkai Tippmann, 1953, from Bolivia, and ZAJcIW (1967) established Dihammaphoroides also for a single species, D. sanguinicollis Zajciw, 1967, from Brazil.

FraGoso (1978) in studying the genitalia of representatives of the Cerambycinae tribes occurring in the America north of Mexico, stated that further studies could indicate Cleomenini as, at most, a subtribe of Rhopalophorini.

Monné (1993) and Monné \& Giesbert (1994) catalogued seven genera and 44 species for the New World.

Mermudes \& NAPP $(2000,2001)$ revised Haenkea, to which they included Dihammaphora atra (Chevrolat, 1855), and transferred Eupempelus to Heteropsini. NapP \& Mermudes (2001a), in revising Listroptera, established Aguassay Napp \& Mermudes, 2001 to accommodate Listroptera collaris (Klug, $1825)$, noticing its great similarity with Rhopalophora. The same authors (2001b) described Timabiara Napp \& Mermudes, 2001, related to Haenkea and Dihammaphora, and emphasized the great uniformity of this group of genera together with Listroptera and Aguassay.

Mermudes \& NapP (2002) presented and discussed the morphology of Fregolia and transferred the genus to Callidiopini.

Finally, Marques \& NapP (2003), in the cladistic analysis of the Rhopalophorini, raised the hypothesis that the Neotropical Cleomenini genera may belong to that tribe.

\section{MATERIAL AND METHODS}

The material examined was provided by: Departamento de Zoologia, Universidade Federal do Paraná, Curitiba (DZUP); Museu Nacional, Universidade Federal do Rio de Janeiro, Rio de Janeiro (MNRJ); Museu de Zoologia, Universidade de São 
Table I. Species examined and geographical distribution. ( ) number of species currently assigned to each Neotropical genus; T, type species; $(*)$ type species not studied.

\section{Tribe Cleomenini}

\author{
Neotropical genera \\ Pandrosos Bates, 1867 - (1) \\ P. phtisicus (Klug, 1825) - Panama and Brazil \\ Haenkea Tippmann, 1953 - (3) \\ H. zischkai Tippmann, 1953 (T) - Brazil and Bolivia \\ H. thoracica (Chevrolat, 1855) - Costa Rica, Panama, \\ Venezuela \\ H. atra (Chevrolat, 1855) - Brazil \\ Listroptera Audinet-Serville, 1834 - (2) \\ L. tenebricosa (Olivier, 1790) (T)-Mexico to Uruguay \\ L. carbonaria (Chevrolat, 1855) - Venezuela \\ Aguassay Napp \& Mermudes, 2001- (1) \\ A. collaris (Klug, 1825) - Brazil \\ Dihammaphora Chevrolat, 1859 - (37) \\ D. marginicollis Chevrolat, 1859 (T) - Brazil \\ D. nigrovittata Fisher, 1937 - Brazil \\ D. nigrita Chevrolat, 1859 - Brazil and Paraguay \\ Dihammaphoroides Zajciw, 1967 - (2) \\ D. sanguinicollis Zajciw, 1967 (T) - Brazil
}

Afrotropical and Oriental genera

Cleomenes Thomson, 1864 (type genus) - Oriental and Indomalaya

C. dihammaphoroides Thomson, $1864(\mathrm{~T})$

C. auricollis Kano, 1933

C. vittatus Pascoe, 1869
Dere White, 1855 - Afrotropical, Oriental and Paleartic

D. thoracica White, $1855(\mathrm{~T})$

D. coeruleipennis Aurivillius, 1924

D. lagria (Jordan, 1903)

Procleomenes Gressit \& Rondon, 1970 - Oriental

P. elongatithorax Gressit \& Rondon, 1970

Artimpaza Thomson, 1864 - Oriental

A. odontoceroides Thomson, 1864 (T)

A. setigera (Schwarzer, 1925)

A. femorata (Pascoe, 1866)

Kurarua Gressit, 1936 - Oriental.

K. constrictipennis Gressit, $1936-(\mathrm{T}) \quad(*)$

K. bicolorata Gressit \& Rondon, 1970

Apiogaster Perroud., 1855 - Afrotropical

A. rufiventris Perroud, $1855-(\mathrm{T}) \quad(*)$

A. collare Jordan, 1903

A. xanthomelas Jordan, 1906

A. posticum Jordan, 1903

\section{Tribe Rhopalophorini}

Rhopalophora collaris (Germar, 1824) - (T) Brazil, Paraguay, Argentina, Uruguay

\section{Tribe Rhinotragini}

Rhinotragus dorsiger (Germar, 1824) - (T) Brazil
Paulo, São Paulo (MZSP); Transvaal Museum of Natural History, Pretoria (TMNH).

The study was based on representatives of the type species of the Neotropical Cleomenini genera and other congeneric species. Dihammaphora, the largest Neotropical genus, was represented by three species: D. marginicollis Chevrolat, 1859 (type species), D. nigrita Chevrolat, 1859 and D. nigrovittata Fisher, 1937. No specimens of Timabiara bahiensis Napp \& Mermudes, 2001 were available for dissection and therefore its study was restricted to the external morphology. Similarly, only the male of Dihammaphoroides sanguinicollis Zajciw, 1967, was dissected.

To draw comparisons with the Neotropical Cleomenini, the morphology of Rhopalophora collaris (Germar, 1824) (type species of Rhopalophora), Cleomenes auricollis Kano, 1933 and $C$. dihammaphoroides Thomson, 1864 (type species of Cleomenes) was studied; likewise, Rhinotragus dorsiger (Rhinotragini) was dissected to determine the taxonomic assignment of Pandrosos. Additionally, the external morphology of representatives of other Oriental and African Cleomenini genera was examined.

Literature data about Rhopalophorini (GIESBERT \& CHEMSAK 1993; Marques \& NAPP 1996, 2003; NAPP \& MARques 1999),
Rhinotragini (Magno 1994) and other non Neotropical Cleomenini, as well as the studies of NAPP (1994) on Cerambycidae interrelationships, were used to support the present study along with the examination of the external morphology of several representatives of the tribes Rhopalophorini and Rhinotragini.

The species studied are listed in Table I.

The techniques and terminology follow NAPP (1994) and Marques \& NAPp (1996). The dark and strongly sclerotized pieces were cleared using hot $\mathrm{H}_{2} \mathrm{O}_{2}$ (20 vol.) for, at most, 3 minutes, and the membranous parts were stained according to Fragoso (1980).

Since most of the species belong to different genera only the name of the genus is used to simplify the presentation. When different species of the same genus are treated, the specific name is given.

\section{RESULTS ANDDISCUSSION}

\section{HEAD}

In Listroptera, Haenkea, Dihammaphora nigrovitatta (Figs. 1-3), D. nigrita and Aguassay the head is about 1/3-1/ 4 longer than the width across the lower eye lobes and 

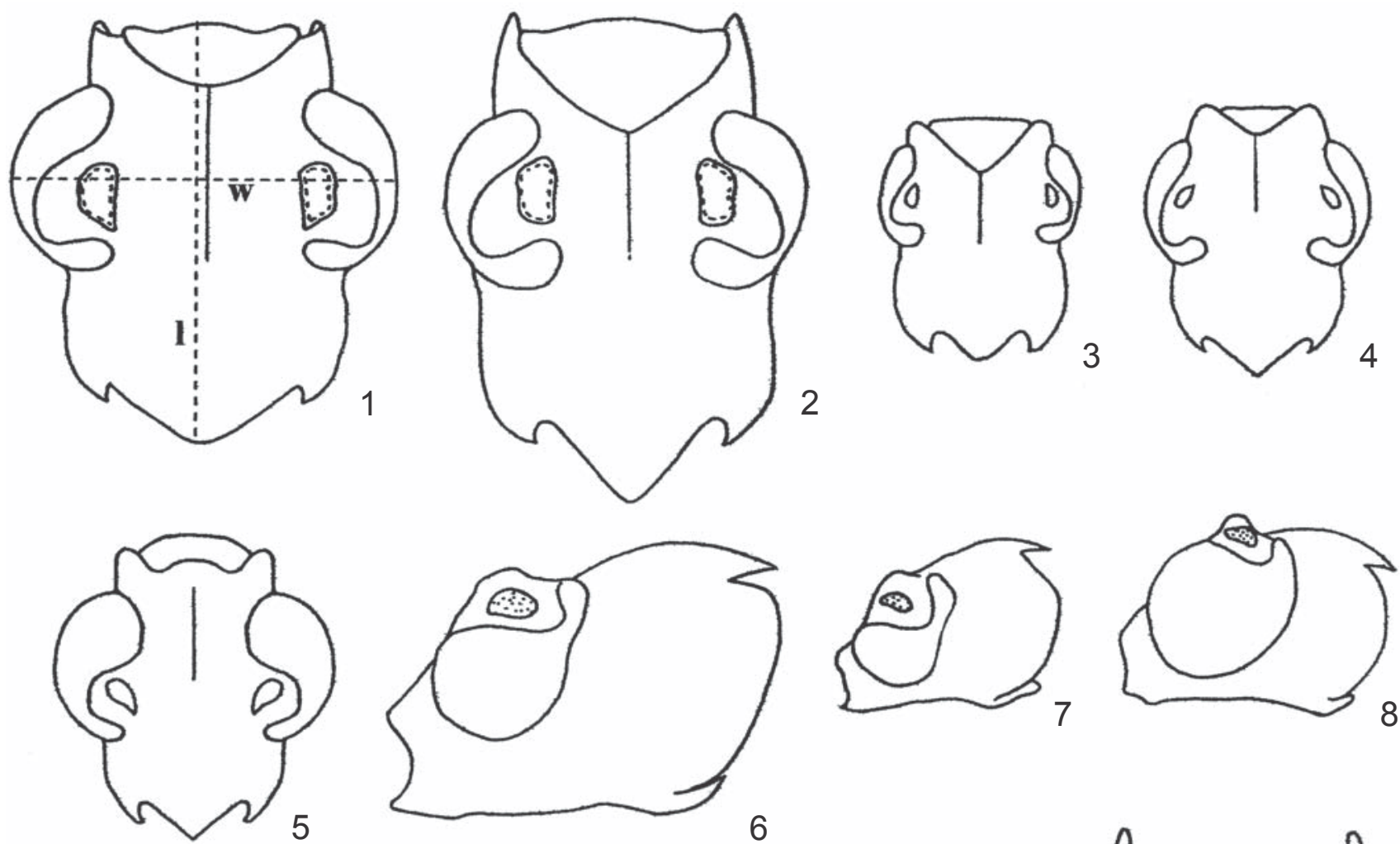

\section{8}
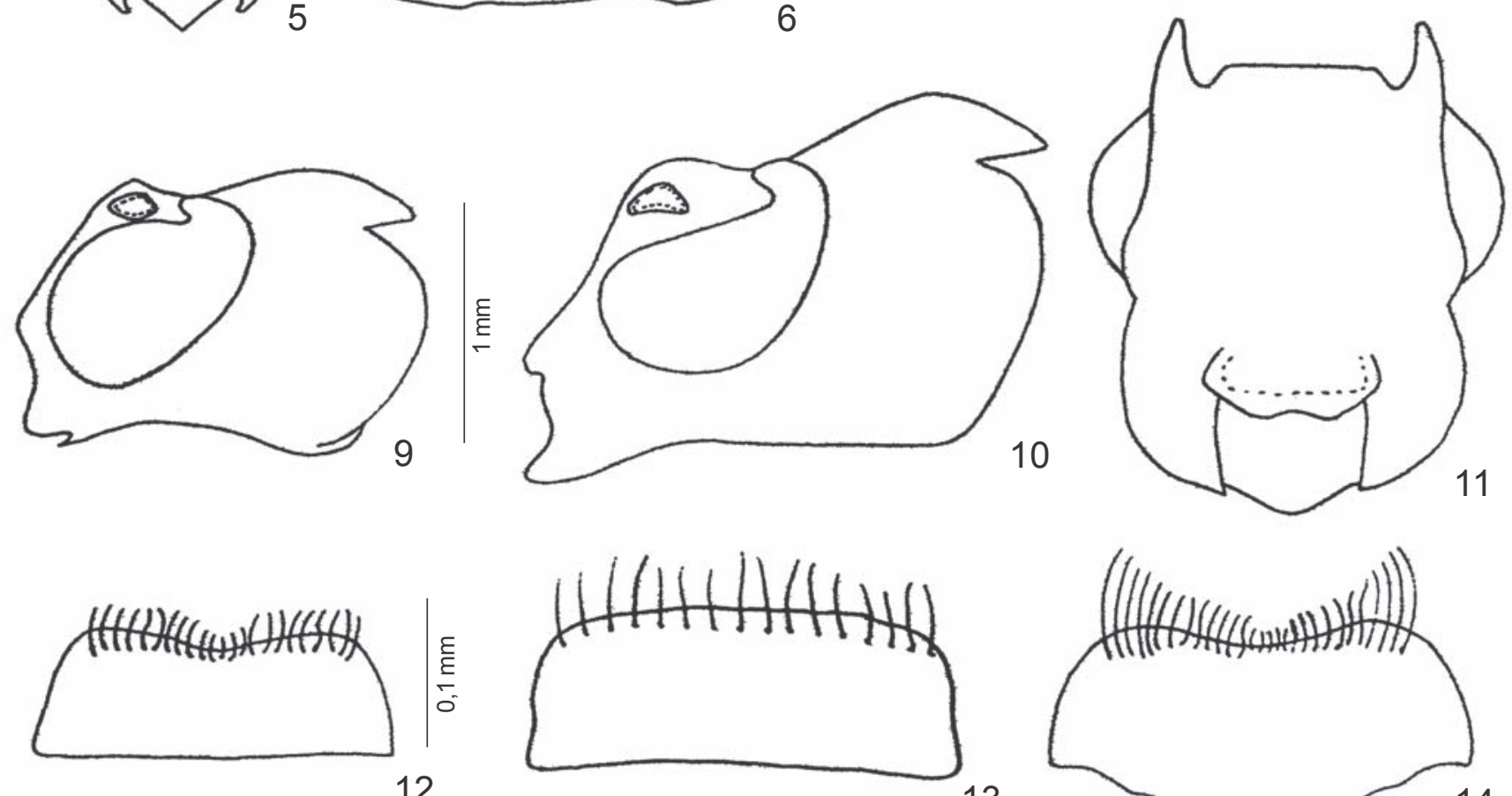

12

13

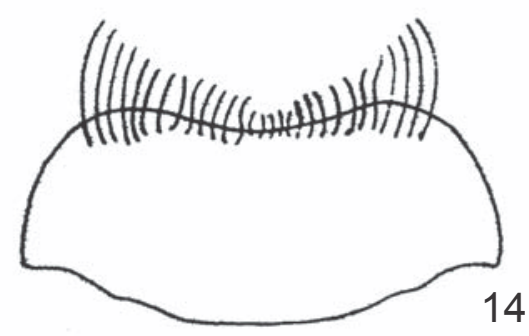

Figs. 1-14. 1-5. Head, dorsal view: 1, Listroptera tenebricosa; 2, Haenkea zischkai; 3, Dihammaphora nigrovittata; 4, Dihammaphoroides sanguinicollis; 5, Pandrosos phtisicus. 6-10. Head, lateral view: 6, Listroptera tenebricosa; 7, Dihammaphora nigrovittata; 8, Pandrosos phtisicus; 9, Cleomenes auricollis; 10, Rhopalophora collaris. 11, Head, ventral view, Haenkea zischkai. 12-14. Labrum: 12, Dihammaphora nigrita; 13, Pandrosos phtisicus; 14, Dihammaphoroides sanguinicollis; $1=$ length; w=width. Figs. 1-11, 12-14, respectively, in the same scale. 

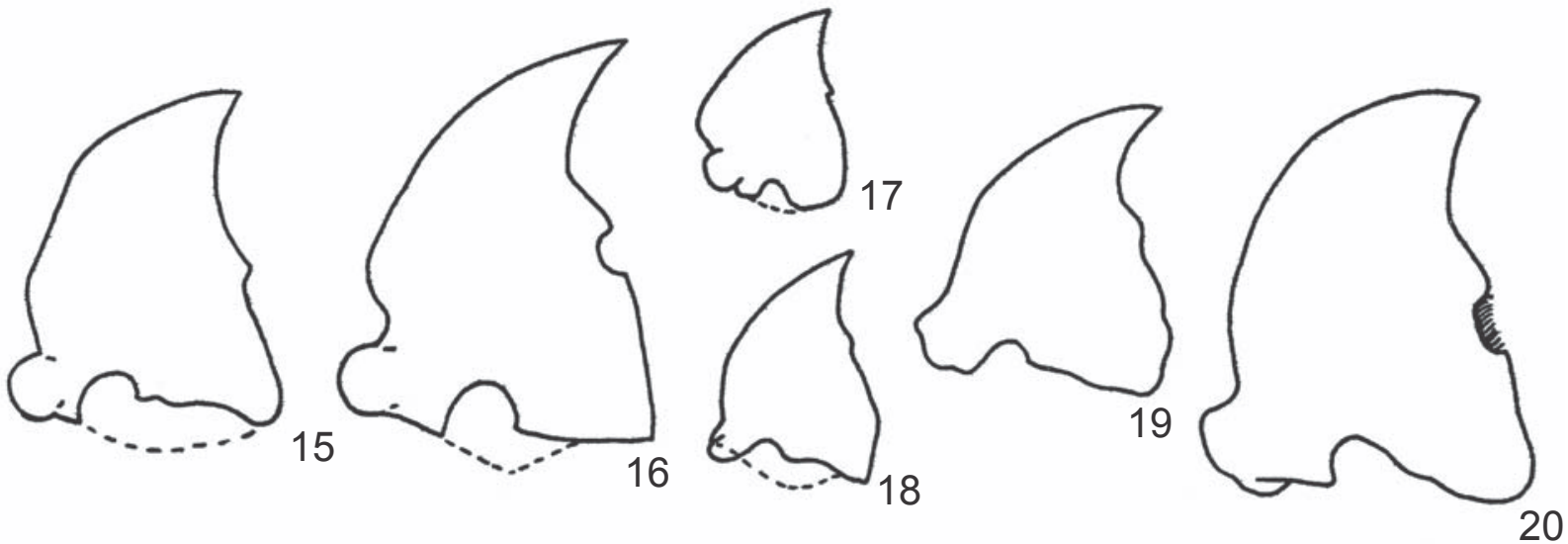

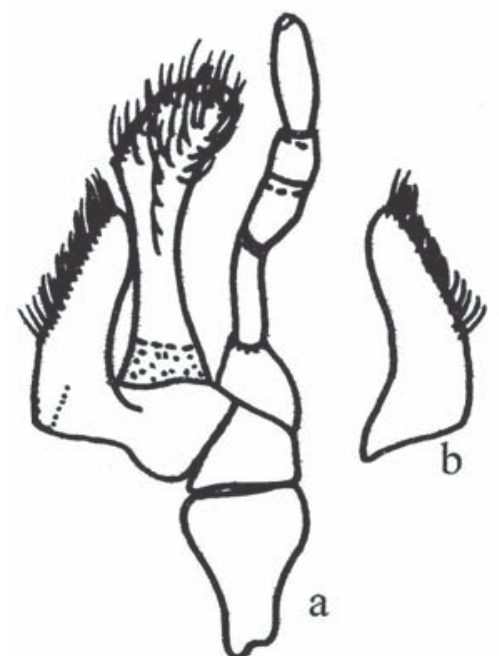

21
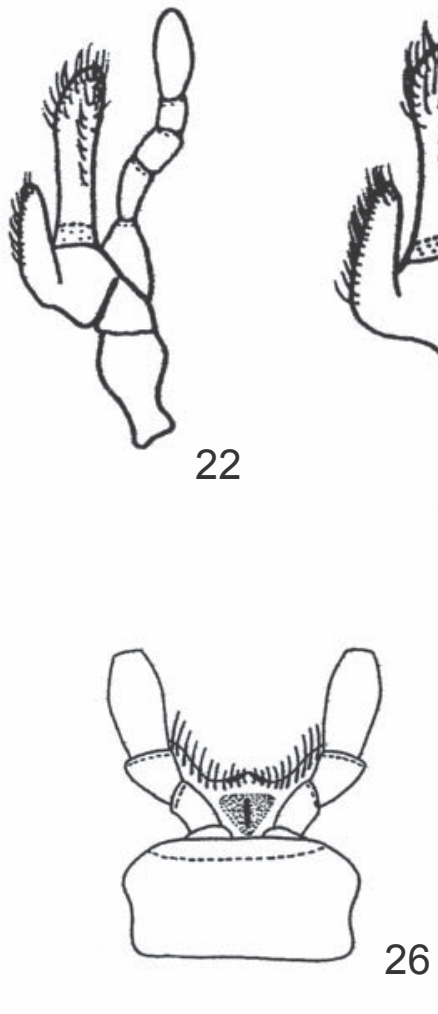

25
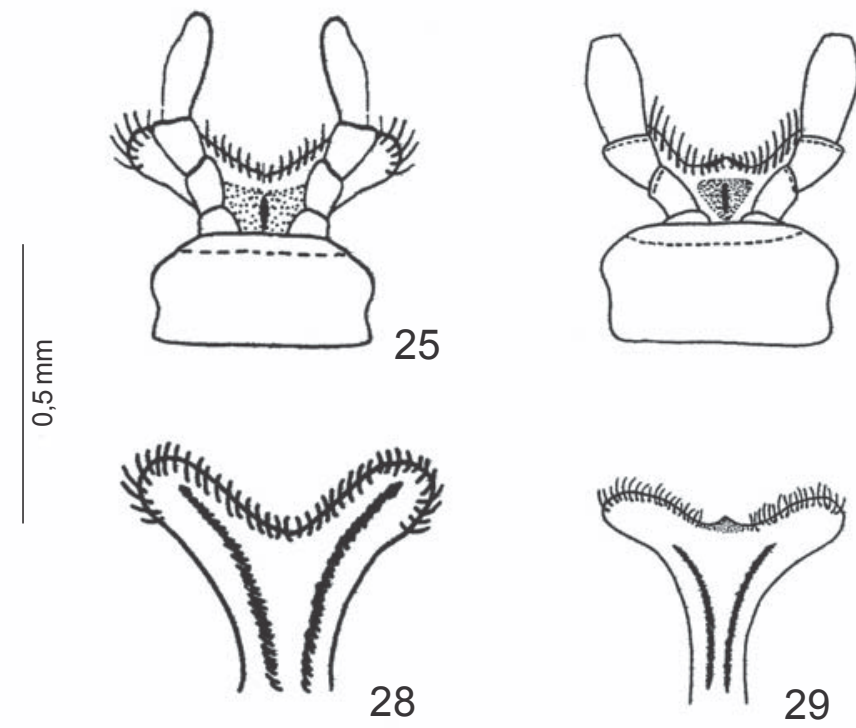
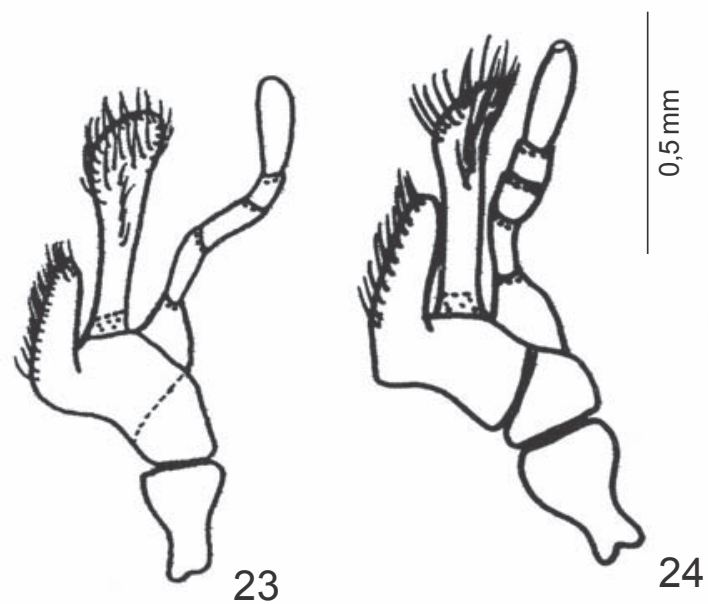

24
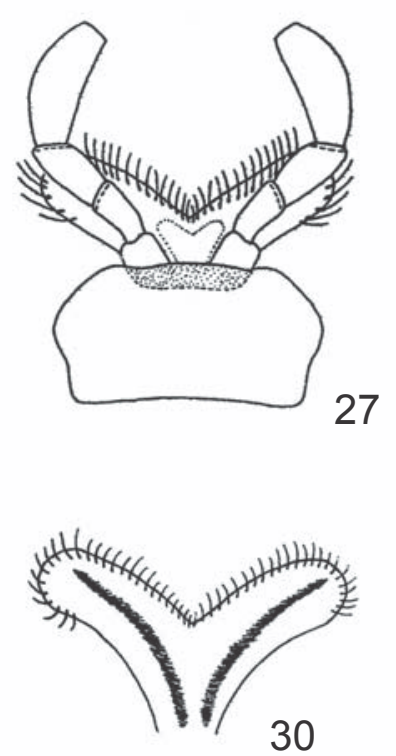

Figs. 15-30. 15-20. Mandibles, dorsal view: 15, Listroptera tenebricosa; 16, Haenkea zischkai; 17, Dihammaphoroides sanguinicollis; 18, Pandrosos phtisicus; 19, Cleomenes auricollis; 20, Rhopalophora collaris. 21-24. Maxillae: 21, Listroptera tenebricosa, a, dorsal, b, lacinia ventral; 22, Pandrosos phtisicus; 23, Cleomenes auricollis; 24, Rhopalophora collaris. 25-27. Labium, ventral view: 25, Listroptera tenebricosa; 26, Dihammaphoroides sanguinicollis; 27, Pandrosos phtisicus. 28-30. Inner surface of ligula: 28, Listroptera tenebricosa; 29, Dihammaphoroides sanguinicollis; 30, Pandrosos phtisicus. 
sinuously enlarged posteriorly; the dorsum is convex, gradually elevated, the vertex always more prominent than the antennal tubercles (Figs. 6, 7). The frons is oblique, as long as or longer than wide. The antennal tubercles are moderately prominent, somewhat acute and the antennal alveoli are on the top of the frons. The distance between the alveoli and mandible insertions is about 1.3 times the lower eye lobe width. The genae are elongate, about as the long as the width of the lower eye lobes. The clypeus is large, as long as $2 / 3$ of the frons length and the clypeal suture is angulated to feebly rounded (Figs. 1-4). The eyes are finely granulate, deeply emarginate, encompassing the bases of the antennae, reaching the inner edge of the antennal alveolus on the frons and dorsally; the posterior is edge sinuous; the portion linking the ocular lobes is narrow and far from the antennal tubercles; the lower lobes are somewhat transverse, moderately prominent, their upper margins far from the antennal alveoli.

The same pattern is observed in Dihammaphoroides (Fig. 4), Dihammaphora marginicollis and Timabiara.The latter two differ only by the vertical frons, shorter and transverse clypeus and shorter genae; Dihammaphoroides by the acute antennal tubercles and eyes more separated on the frons.

Pandrosos (Figs. 5, 8) shows several similarities with the Rhinotragini: the head is short, subparallel sided and flattened behind the eyes; the frons is longer than wide and strongly declived; the antennal tubercles are more prominent than the vertex; the lower eye lobes are very large and approximate on the frons, especially in males, and the portion joining the lower and upper lobes is as wide or even wider than the upper lobe. This kind of eyes is very similar to those of Rhinotragini.

In all the genera, the submentum is short and transverse and the gular sutures are short and convergent or a little longer and sinuously convergent (Fig. 11).

The head shape of Listroptera, Aguassay, Haenkea, Timabiara, Dihammaphora and Dihammaphoroides is similar in both Cleomenes (Fig. 9) and Rhopalophora (Fig. 10). It is, however, more similar to the latter by the elongate genae and eyes with transverse lower lobes with the upper margins and the portion linking the eye lobes distant from the antennal tubercles. The latter two conditions have been considered synapomorphies of Rhopalophorini (MARQUES \& NAPP 2003). In Cleomenes (Fig. 9) the eyes are very large and prominent; the portion joining the upper and lower lobes is also very broad and the posterior margin of the eyes is rounded; the genae, despite the enlargement of the eyes, are short; in addition, the head is as broad as long, shorter and not enlarged posteriorly.

Pandrosos is more similar to Rhinotragus by the head and eyes shape. BATES (1870) considered the eyes proximate on the frons as an essential character to define Rhinotragini; however, this condition may be variable to some extent as noticed by NAPP \& MERMUdes (1999).

\section{MOUTHPARTS}

Labrum. The labrum (Fig. 12) is transverse with sides weakly converging to the bissinuate apex in Listroptera, Aguassay,
Haenkea, Dihammaphora, Timabiara and also in Rhopalophora, unlike Cleomenes, in which the labrum is quadrangular. Dihammaphoroides (Fig. 14) differs by having the labrum rounded at the sides and feebly emarginate apically. In Pandrosos (Fig. 13) the labrum is subparallel at the sides and the apex is truncate, a shape not observed in any other studied Cleomenini, but present in Rhinotragus.

Mandibles. Listroptera, Haenkea, Dihammaphora, Timabiara and Aguassay have slender mandibles (Figs. 15, 16), about as long as or a little longer than the width across the base, very weakly angulate externally, with a more or less acute, somewhat projected and curved apex; the inner cutting edge is fringed from near the base up to the apical third (except Aguassay and D. marginicollis), and with a median, somewhat developed tooth (two teeth in D. marginicollis), followed by a rounded notch (more evident in Haenkea, Fig. 16), except in Aguassay. These features are similar to those of Rhopalophora (Fig. 20), differing from Cleomenes (Fig. 19) in which the mandibles are as wide as long, not angulate externally, with a small, blunt tooth at the inner cutting edge that lacks the rounded notch.

In Dihammaphoroides and Pandrosos (Figs. 17, 18), the mandibles are a little longer than wide, conspicuously rounded externally; the inner cutting edge has a very small tooth, lacking a rounded notch; the apex is acute, not curved. Nevertheless, the mandibles of Pandrosos are more similar to those of Rhinotragus by their laminar aspect and the aforementioned features.

Maxillae. In all the Neotropical Cleomoenini examined, the maxillae (Fig. 21) present: cardo well developed; stipes divided into basistipes and dististipes; galea with the bases withdrawn between the palpiger and lacinia, fold-like, giving the galea the possibility to become distended, the basal segment represented by a well developed, sclerotized ring. In Listroptera, Aguassay, Haenkea, Dihammaphora, Timabiara and Dihammaphoroides the galea is almost as long as the palp, cylindrical and strongly enlarged apically, with the inner edge obliquely truncate; the pilosity is long, dense and the hairs capitate; the lacinia is elongate and well developed, with the outer margin oblique apicad from the middle, with compact setae longer near apex. The palpi have the basal segment as long as the apical which is cylindrical, attenuated at the apex; the second and third segments are short and conical, the former slightly longer; the palpiger is developed and far from the lacinia.

Pandrosos (Fig. 22) differs by the cylindrical galea, feebly expanded apically, lacinia less developed and basal segment of the palpi shorter than the apical segment.

The cylindrical galea, as long as the palp, enlarged apically and obliquely truncate is a synapomorphy of Rhopalophorini (Marques \& Napp 2003). However, Listroptera, Aguassay, Haenkea, Dihammaphora, Timabiara and Dihammaphoroides may be distinguished from both Cleomenes (Fig. 23) and Rhopalophora (Fig. 24) by the 

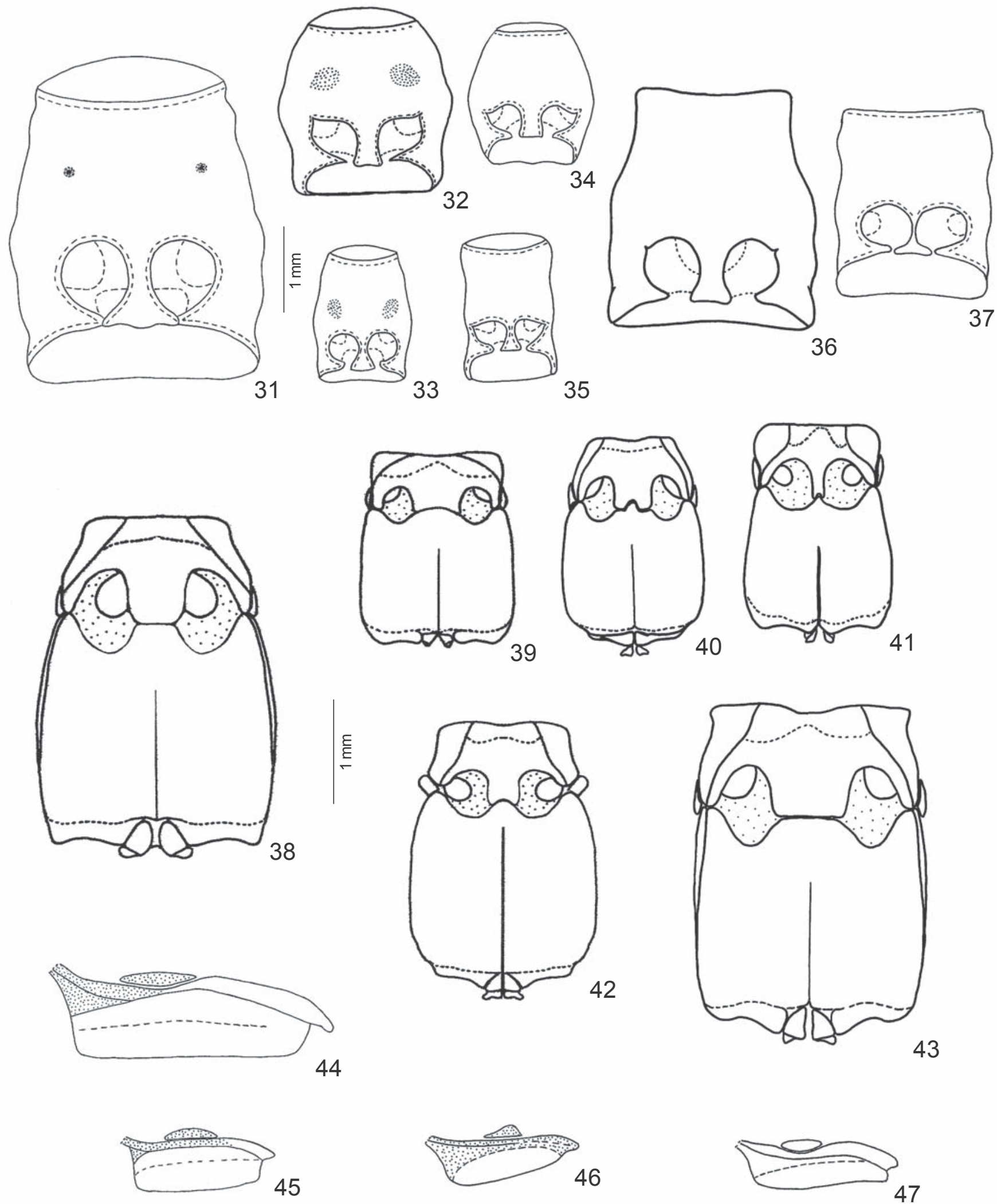

Figs. 31-47. 31-37. Prothorax, ventral view: 31, Haenkea zischkai; 32, Listroptera tenebricosa; 33, Dihammaphora nigrovittata; 34, Dihammaphoroides sanguinicollis; 35, Pandrosos phtisicus; 36, Rhopalophora collaris; 37, Cleomenes auricollis. 38-43. Mesosternum and metasternum: 38, Haenkea zischkai; 39, Listroptera tenebricosa; 40, Dihammaphoroides sanguinicollis; 41, Pandrosos phtisicus; 42, Cleomenes auricollis; 43, Rhopalophora collaris. 44-47. Metepimeron and metepisternum: 44, Haenkea zischkai; 45, Dihammaphoroides sanguinicollis; 46, Pandrosos phtisicus; 47, Cleomenes auricollis. Figs. 31-37, 38-47, respectively in the same scale. 
following characters combined: galea strongly expanded apically, lacinia well developed and the second segment of the palpi longer than the third.

Labium. Listroptera, Aguassay, Haenkea, Timabiara and Dihammaphora have a similarly shaped labium (Fig. 25). The mentum is quadrangular, slightly more transverse in Listroptera, constricted at the sides at the posterior half. The ligula (Figs. 25, 28) is membranous, deeply emarginated, with well developed lateral lobes reaching the base of the apical segment of the palpi; the outer surface has a median, pigmented area provided with long hairs and the pilosity of the inner surface is arranged into two narrow, lateral stripes of short, dense hairs (the latter two features could not be observed in Timabiara). The palpiger is free, the two basal segments of the palpi conical, similarly-sized and the apical segment is cylindrical, attenuate at base and apex.

In Dihammaphoroides (Fig. 26) the mentum is more transverse, widening at the anterior half; the ligula (Fig. 29) is narrow, subparallel at the sides, enlarging only apically forming rounded, lateral lobes; the apical margin is shallowly emarginate and has an acute, sclerotized projection at middle; the apical segment of the palpi is truncate at the apex.

Pandrosos (Fig. 27) has a transverse, weakly constricted mentum, which is narrower posteriorly; the ligula (Fig. 30) is membranous with the lateral lobes well developed and the median notch deep and angulate; the apical segment of the palpi is attenuated apically, arcuate externally and the second segment is longer than the basal segment.

The labium of Listroptera, Aguassay, Haenkea, Timabiara and Dihammaphora is similar to those of Rhopalophora and Cleomenes. However, the quadrangular mentum as occurring in Rhopalophora and in the Neotropical Cleomenini, was considered as a synapomorphy of the Rhopalophorini (MARQuES \& NAPP 2003), differing from Cleomenes that has a transverse mentum. Pandrosos differs by the deep, angulate median notch of the ligula and Dihammaphoroides by the general shape of this structure.

\section{ANTENNAE}

The antennae are 11-segmented (except Timabiara and some species of Dihammaphora, with 10 segments), unarmed and quite variable (Figs. 118-126)

Haenkea, Timabiara, Dihammaphora, Dihammaphoroides and Listroptera have subserrate antennae. In the first four genera, the antennae are shorter than the body in both sexes, reaching or barely surpassing the middle of the elytra. Haenkea and Timabiara (Figs. 119, 120) have: segments 3-11 (10 in Timabiara) short, laterally expanded from 6 , especially the $6^{\text {th }}$ which is pyramidal; 3 and 4 shorter than scape and than segments 5 to 7 ; the scape is deeply sulcate in Haenkea. In Dihammaphora and Dihammaphoroides the segments from 7 (or 8) are clearly shortened. In Dihammaphora (Figs. 121-123), segment 2 is half as long as 3 , segments 3 to 5 are subequal in length, as long as the scape, the latter sulcate in D. nigrovittata. In
Dihammaphoroides (Fig. 125), segment 3 is clearly longer than each the scape and segment 4; segments 3 to 8 are bicarinate and sulcate dorsally and ventrally, the carinae vanish on the following segments.

Listroptera (Fig. 118) has a similar shape, although the antennae exceed the elytral apices by two segments in males; the scape is sulcate and longer than segment 3 ; segments 3 to 5 are expanded apically, segment 4 is the shortest, segment 5 is a little longer than 3 ; segments 6 to 10 , unlike the preceding genera, are elongate, subfiliform, weakly depressed.

Therefore, the only features shared by these genera are the subserrate segments and the antennal length, in accordance to LACORDAIRE's (1869) Cleomenini description. Nevertheless, the antennae differ not only among the genera but also from Rhopalophora and Cleomenes (Figs. 127-129) being more useful in the diagnosis of each genus. The elongate, sulcate scape is the only character observed to occur in Rhopalophora and in Listroptera, Haenkea and some Dihammaphora species.

However, the antennae of Aguassay (Fig. 124) are very similar to those of Rhopalophora, as noticed by NAPP \& Mermudes (2001 a): filiform and longer than the body in both sexes, with segment 4 half as long as 3 , segments from 5 longer than 3 , besides the elongate, sulcate scape. On the other hand, a few similarities were observed between Dihammaphoroides and Cleomenes (Figs. 125, 127-128), such as the length of the basal segments and shortening of segments 6 to 11 ; but segment 4 is short and segments 3 to 8 are conspicuously bicarinate and sulcate, features not found in Cleomenes.

Pandrosos (Fig. 126) has antennae similar to those observed in the Rhinotragini, with cylindrical basal segments, the distal segments thickened and expanded apically. In this genus, segment 3 is about 2/3 longer than the scape, twice as long as segment 4 and longer than segment 5 ; the remaining segments are longer than 5, thicker and expanded apically and segment 11 is appendiculate. The antennae exceed the elytral apices by one segment in males.

\section{THORAX}

Prothorax. Haenkea, Timabiara and Dihammaphora (Figs. 119-123) are the most similar concerning the prothorax. In these genera, it is longer than broad, subcylindrical, attenuated from middle to apex, sinuous at sides. The coxal cavities (Fig. 31) are rounded at the sides and closed behind (varying in Dihammaphora, Fig. 33) by the proepimeron that projects a little beyond the middle of the cavity contacting the widened apex of the intercoxal process. The prosternum is depressed, raising to the intercoxal process which is narrowed between the procoxae, than gradually expanded apically. The sexual punctation is variable. In males of Haenkea it is represented by a single, coarse, deep puncture on each side of the prosternum, an exclusive character (Mermudes \& NAPP 2000, figs. 4-5). Timabiara and some species of Dihammaphora have an opaque, glabrous patch on each side in front of the coxae, impunctate in Timabiara and finely, densely punctate in 


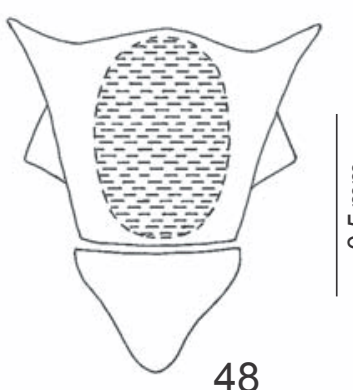

48

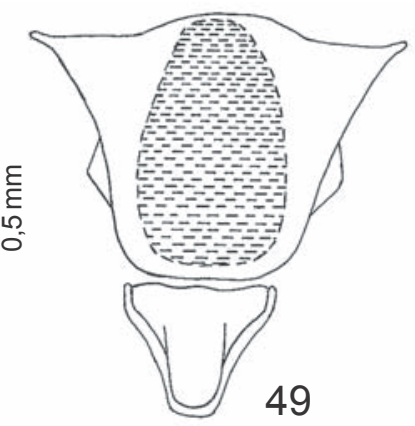

49
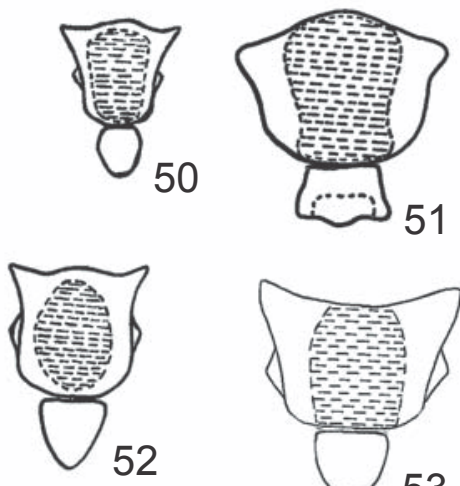

52

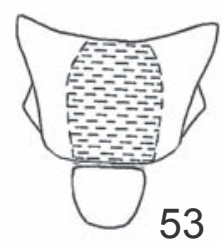

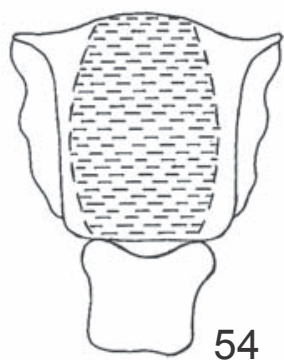
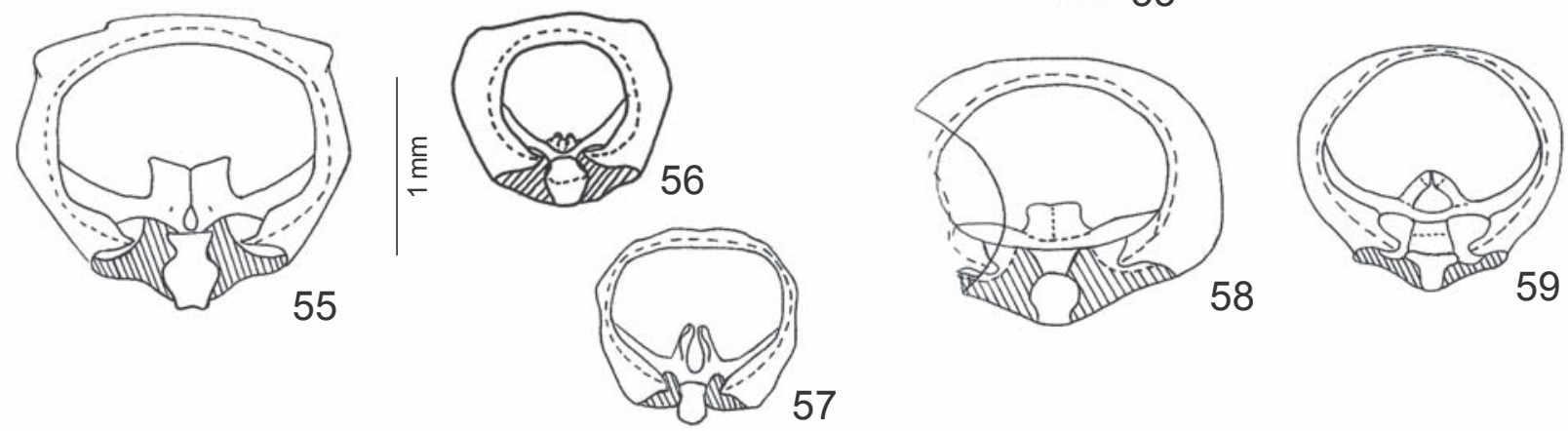

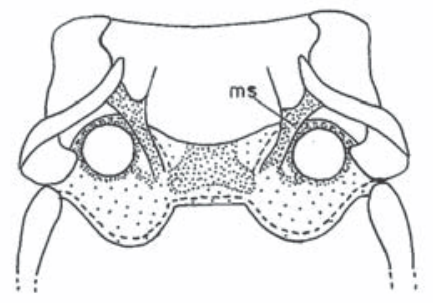

60

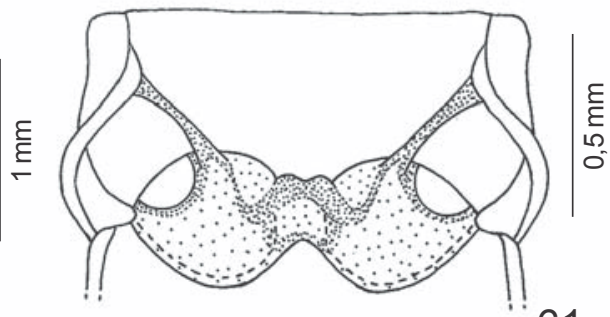

61

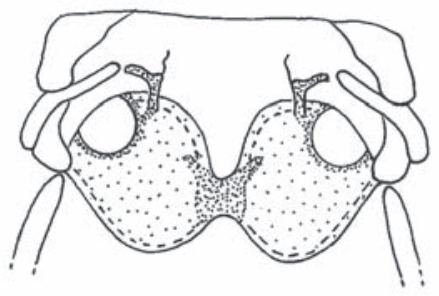

62

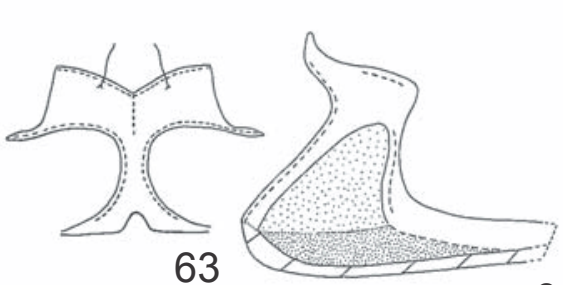

64

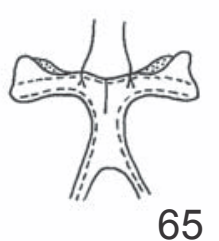

65

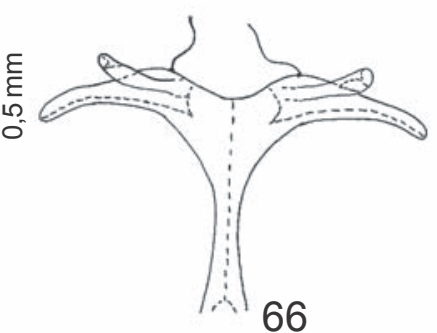

66

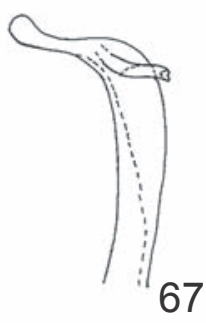

67
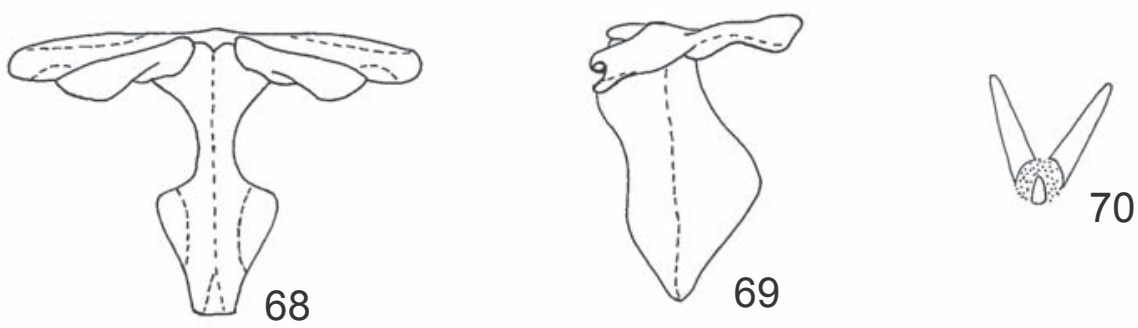

Figs. 48-70. 48-54. Mesoscutum and scutellum: 48, Listroptera tenebricosa; 49, Haenkea zischkai; 50, Dihammaphora nigrita; 51, Dihammaphoroides sanguinicollis; 52, Dihammaphora nigrovittata; 53, Pandrosos phtisicus; 54, Cleomenes auricollis. 55-59. Proendosternite: 55, Listroptera tenebricosa; 56, Dihammaphoroides sanguinicollis; 57, Pandrosos phtisicus; 58, Rhopalophora collaris; 59, Cleomenes auricollis. 60-62. Mesendosternite: 60, Listroptera tenebricosa; $\mathrm{ms}=$ mesendosternite; 61, Dihammaphoroides sanguinicollis; 62, Pandrosos phtisicus. 6369. Metendosternite: 63, Listroptera tenebricosa, dorsal; 64, Haenkea zischkai, lateral; 65, Dihammaphoroides sanguinicollis, dorsal; 66, 67, Pandrosos phtisicus, dorsal and lateral; 68, 69, Cleomenes auricollis. 70, empodium, Haenkea zischkai. Figs. 48-54, 55-59, 61-62, 63-70, respectively, in the same scale. 
Dihammaphora (sexual punctation is missing in $D$. marginicollis).

Aguassay (Fig. 124) has a similar prothorax, but gradually attenuated from base to apex and the anterior coxal cavities are open behind; the sexual punctation is formed by a small impressed area, coarsely punctate on each side of prosternum (see also NAPP \& MERmudes 2001a).

In Listroptera (Fig. 118) the prothorax is about as wide as long, moderately tuberculate on each side at middle, but also attenuated from base to apex. The pronotum has four gibbosities and the prosternum is flattened. The anterior coxal cavities are slightly angulate at sides and narrowly open behind (Fig. 32). The intercoxal process is half as wide as the procoxa, expanded apically. As in the preceding genera, the proepimeron projects almost to the intercoxal process. The sexual punctation in males is formed by a subrounded, subglabrous, densely punctate patch on each side of the prosternum.

The prothorax of Dihammaphoroides (Fig. 125) has some similarities with those of the preceding genera. It is longer than broad, but rounded at the sides, widest at middle. The prosternum is flattened; the anterior coxal cavities and the intercoxal process are similar to those of Listroptera, but the latter is more parallel at the sides and not expanding apically (Fig. 34).

Pandrosos (Fig. 126) has the prothorax cylindrical, the base as wide as the apex, sinuous and weakly tuberculate at the sides, constricted at the basal and apical third. The pronotum is conspicuously longer than the prosternum (Fig. 35). The coxal cavities are large, close to each other and narrowly open behind; the intercoxal process is narrow between the coxae, expanded apically with the apex sinuous (Fig. 35).

Mesothorax. The mesosternum (Figs. 38, 39) is about half as long as the metasternum in Haenkea, Dihammaphora, Aguassay, Timabiara and Dihammaphoroides; shorter in Listroptera. The intercoxal process is 1.5 times as broad as the coxal cavity (except in Dihammaphoroides, as broad as the cavity width); the intercoxal process is prominent (except in Timabiara, subplane). Only in Dihammaphoroides (Fig. 40) the metasternum fits into a notch at the apex of the intercoxal process of the mesosternum. In the other genera the anterior median part of the metasternum is as wide as the intercoxal process of the mesosternum and both apices are truncate, juxtaposed and strongly connected. The intermediate coxal cavities are closed externally.

In Pandrosos (Fig. 41) the mesosternum is transverse, clearly narrowed laterally. The intercoxal process is not prominent, narrow, as wide as $1 / 3$ of the coxal cavity width, parallel at sides, the apex emarginate. The coxal cavities are plenty large and closed externally.

Metathorax. The metasternum (Figs. 38-40) is moderately convex, with the lateral margins somewhat rounded, longer than broad in Haenkea, Aguassay, Timabiara, Dihammaphora and Dihammaphoroides and as long as broad in Listroptera. On each side, in front of the metacoxae, there is a transverse, narrow impression, more evident in Haenkea. The metepimeron (Fig. 44) is produced apically partially encompassing the metacoxa externally, except in Dihammaphoroides, in which the metepimeron is slightly produced (Fig. 45). The metepisternum (Figs. 44, 45) is broad, somewhat flattened, with parallel sides, longitudinally carinate and evenly sclerotized throughout.

In Pandrosos (Fig. 41) the metasternum is a little longer than broad, somewhat widening backwards; the anterior margin is projected medially to fit into a notch at the apex of the mesosternal process. The metepimeron (Fig. 46) is narrow, slightly produced at apex and the suture between the episternum and epimeron is vanishing anteriorly. The metepisternum is moderately broad, narrowed behind, sclerotized ventrally below the carina and membranous dorsally above the carina.

Mesoscutum and scutellum. Listroptera, Haenkea, Aguassay and Dihammaphora have a similar type of mesoscutum and scutellum (Figs. 48-50, 52): the stridulatory plate is large and oval, very finely striate; the anterior margin of the mesoscutum is rounded between narrow, elongate, lateral projections. The scutellum is triangular, differing little among the genera: impressed along the lateral margins with the apex rounded-truncate in Haenkea (Fig. 49); not impressed with the apex acuminate in Listroptera (Fig. 48) or slightly emarginate in Aguassay. Some minor differences were also observed among the examined species of Dihammaphora regarding the stridulatory plate, the anterolateral projections of the mesoscutum and shape of the scutellum. In Dihammaphora marginicollis and D. nigrita (Fig. 50) the lateral projections are narrow; the scutellum is narrowed at the apical third and the apex is, respectively, emarginate and rounded truncate; in D. nigrovittata (Fig. 52), the lateral projections are broader and the scutellum, subtriangular.

In Dihammaphoroides (Fig. 51) the mesoscutum is as long as broad, with the anterior margin rounded, projecting between the short lateral projections; the stridulatory plate is prominent along the middle and constricted at the posterior half; the scutellum is transverse with the sides sinuously divergent, the apical region is impressed and the apex is truncate, weakly projected at the middle.

In Pandrosos (Fig. 53) the anterior margin of the mesoscutum is emarginated and the lateral projections are well developed and broad; the scutellum is quadrangular, roundedtruncate at apex.

Endosternites. In Listroptera, Haenkea, Dihammaphora nigrita, D. nigrovittata and Aguassay the proendosternite (Fig. 55) is quadrangular, moderately developed, entirely fused along the median line and directed toward the dorsum of the pronotum; $D$. marginicollis differs only by the subtriangular shape of the proendosternite. In Dihammaphoroides (Fig. 56) it is very much reduced and not fused. The mesendosternite (Figs. 60) is strongly sclerotized, straight and obliquely directed towards the mesepimeron, the apex feebly expanded and fused 

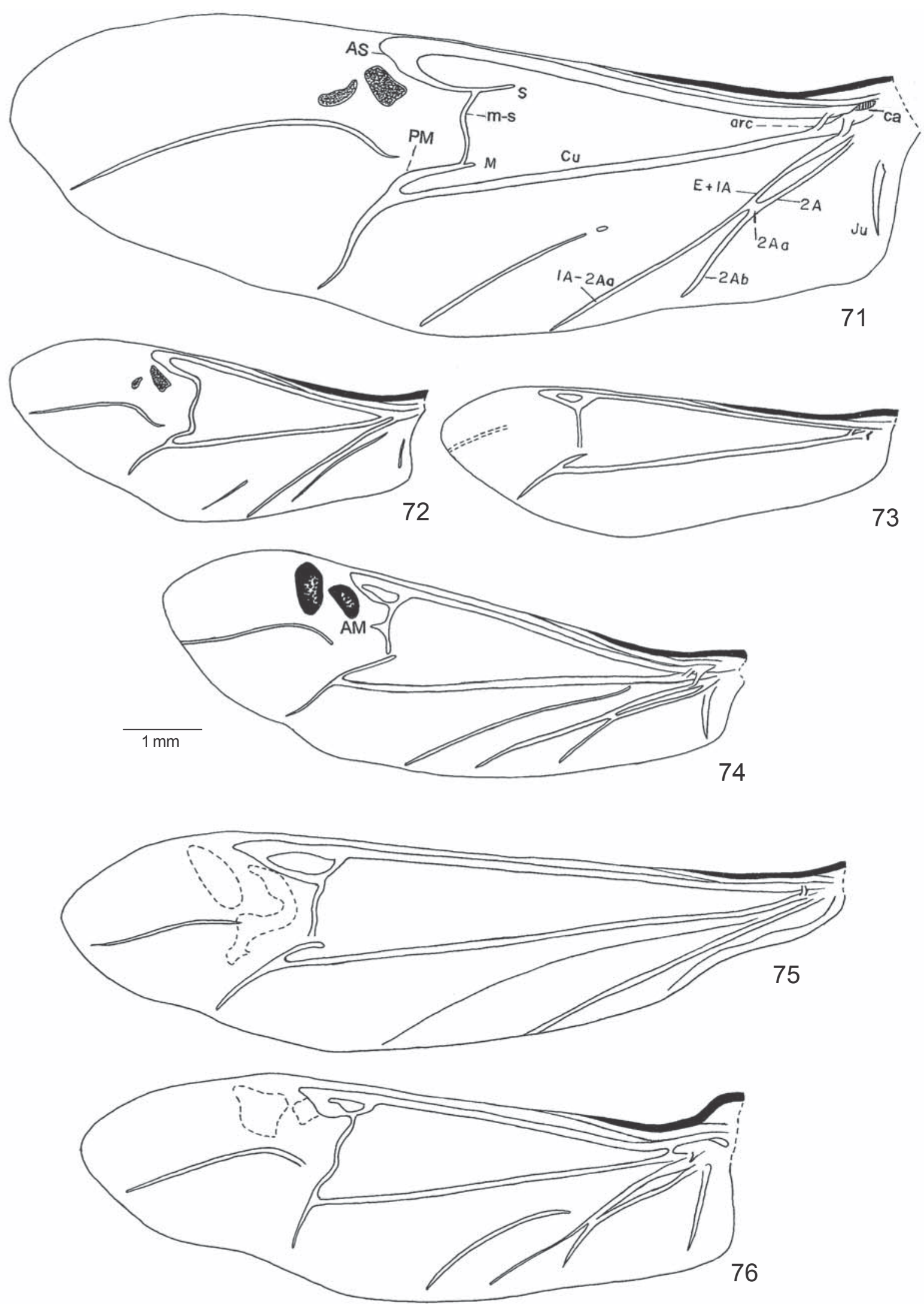

Figs. 71-76. Wings: 71, Listroptera tenebricosa; 72, Dihammaphora nigrovittata; 73, Dihammaphoroides sanguinicollis; 74, Pandrosos phtisicus; 75, Cleomenes auricollis; 76, Rhinotragus dorsiger. AS = Anterior Sector; $\mathrm{AM}=$ Anterior Media; $\operatorname{arc}=\operatorname{arculus;} \mathrm{ca}=\mathrm{carinate}$ area; Cu $=$ Cubitus; $\mathrm{E}=$ Empusal; Ju = Jugal; $\mathrm{M}=$ Media; $\mathrm{PM}=$ Posterior Media; $\mathrm{S}=$ Sector; $\mathrm{m}-\mathrm{s}=$ transverse sector-media; $1 \mathrm{~A}=1^{\text {st }} \mathrm{Anal} ; 2 \mathrm{~A}=2^{\text {nd }} \mathrm{Anal} ; 2 \mathrm{Aa}$ $=$ branch $\mathrm{a}$ of $2^{\text {nd }}$ Anal; $2 \mathrm{Ab}=$ branch $\mathrm{b}$ of $2^{\text {nd }}$ Anal. 
to the inner surface of the latter; the projections for tendons insertion are greatly reduced, lacking in Dihammaphoroides (Fig. 61); between the arms of the mesendosternite and, apparently, joining them, there is a hard, prominent, semicoriaceous area continuous with the membrane lining the coxal cavities. The metendosternite (Figs. 63, 64) has the lateral lamina fused to the lateral arms; the anterior tendons are close to each other and the peduncle is short and entirely fused to the inner wall of the metasternum; in Dihammaphoroides (Fig. $65)$ the region of the fused lateral arms and lamina is narrower. The proendosternite of Pandrosos (Fig. 57) is cylindrical, with the projections subparallel and separated. The mesendosternite (Fig. 62) is angulate, having lateral projections for tendons insertion; the distal part is as long as the basal part and not fused to the mesepimeron at the apex. The metendosternite (Figs. 66, 67) has free lateral lamina and arms; the lamina are moderately long, separated by a shallow, narrow notch and the arms are short; the peduncle is elongate and narrow, not fused to the metasternum, and the projections for tendons insertion are somewhat separated.

The prothorax of Haenkea, Timabiara, Dihammaphora, Listroptera and, mainly, Aguassay (Figs. 118-124) is similar to that of Rhopalophora (Fig. 129) differing greatly from Cleomenes (Figs. 127-128). Even in Dihammaphoroides (Fig. 125) the prothorax is more similar to the Rhopalophorini. Similarly, the intercoxal process of the prosternum (Figs. 3134 ) is like that observed in Rhopalophorini (MARQUES \& NAPP 2003) and much different from the intercoxal process of Cleomenes (Fig. 37) which is very narrow and subparallelsided, suddenly enlarged at the apex. In addition, the Neotropical Cleomenini genera mentioned above share the following synapomorphies reported by MARQUES \& NAPP (2003) for the Rhopalophorini: proendosternite quadrangular, fused medially (Figs. 55, 58) (except Dihammaphoroides, Fig. 56), intercoxal process of the mesosternum broader than the coxal cavity and strongly attached to the equally broad anterior margin of the metasternum (Figs. 36, 39, 43) (except Dihammaphoroides, Fig. 40); metendosternite (Figs. 63, 64) with lateral lamina and arms fused, the peduncle entirely fused to the inner wall of the metasternum.

Unlike the preceding genera, in Cleomenes the proendoesternite is cylindrical and fused only at the apex (Fig. 59), the intercoxal process of the mesosternum is narrower than the mesocoxal cavity and emarginate at the apex (Fig. 42) and the metendosternite has the peduncle, lateral lamina and arms free (Figs.59, 42, 68-69).

The metepisternum is flat, broad and parallel-sided (Figs. $44,45)$ as also observed in Rhopalophora, while in Cleomenes it is somewhat convex and narrowed behind (Fig. 47). On the other hand, the mesendosternite (Fig. 60) not apically enlarged with projections for tendons insertion, though reduced, seems to be more similar to that observed in Cleomenes.

Dihammaphoroides shows some exclusive features: intercoxal process of the mesosternum notched at apex to fit the anterior projection of the metasternum (Fig. 40), transverse scutellum (Fig. 51), greatly reduced proendosternite (Fig. 56), mesendosternite without projections for tendons insertion and metendosternite with the region of the fused lateral arms and lamina, narrow (Figs. 61,65).

Pandrosos is similar to the Rhinotragini with regard to the shape of the prothorax (Fig. 126), the anterior and intermediate coxal cavities (Figs. 35, 41), the metepisternum, the intercoxal process of mesosternum and the metendosternite (Figs. 46, 41, 66-67). The shape of the coxal cavities is typical of exserted, globose, proximate coxae. Also, the endosternites are much different from those presented by all the preceding genera.

Despite of the observed diversity, in all the genera the anterior coxal cavities are rounded at the sides, the closure of the procoxal cavities at the posterior margin made up by the expanded apex of the prosternal process together with the projection of the proepimeron, and the intermediate coxal cavities are closed externally.

Elytra. Haenkea, Dihammaphora, Timabiara and Listroptera (Figs. 118-123) are the most similar with regard to the elytra. In these genera the elytra are relatively short and broad, strongly flattened, impressed at the base near the scutellum and sinuously widened behind the middle; each elytron has two costae: one strong extending from humerus to apex above the vertical epipleurae, another less prominent extending from inside humerus to the apical third. The epipleurae are vertical, longitudinally impressed, costate along the outer margin, the costae are asperate punctate (variable in Dihammaphora, Figs. 121-123). The punctation is coarse, arranged in well defined rows or denser and not seriate, and the surface is clothed with very short, whitish pubescence not obscuring the punctures. Several of these features are also found in the Rhopalophorini, such as the flattened elytra, prominent humeri, vertical epipleurae and vestiture. Also, some species of Rhopalophora also have asperate epipleurae (Giesbert \& Chemsak 1993). The elytra of Aguassay (Fig. 124) are very similar to those of Rhopalophora (Fig. 129) being more elongate, weakly widened behind the middle and without dorsal costae (see also NAPP \& Mermudes 2001a). In the three examined species of Cleomenes (Figs. 127, 128) the elytra also have coarse, dense, more or less seriate punctures and may be clothed with whitish pubescence; however, they are narrow and elongate, not depressed, subparallel at the sides and lack costae; the epipleurae are gradually declivous, neither costate nor asperate and the humeri are not prominent.

Dihammaphoroides (Fig. 125) has similarities with both the preceding genera and with Cleomenes, in addition to some exclusive features. As in Cleomenes the elytra are narrow and very elongate, up to four times as long as the width across the humeri, weakly sinuous at sides, not widened behind the middle and the dorsal costae are inconspicuous. On the other hand, the elytra are depressed, mainly near the scutellum, laterally costate and the epipleurae are vertical as in Dihammaphora and allied genera. It should be noted that some species of Rhopalophora (e.g. R. lineicollis Chevrolat, 1859) also have elongate, subparallel elytra. Unlike all other genera, in 

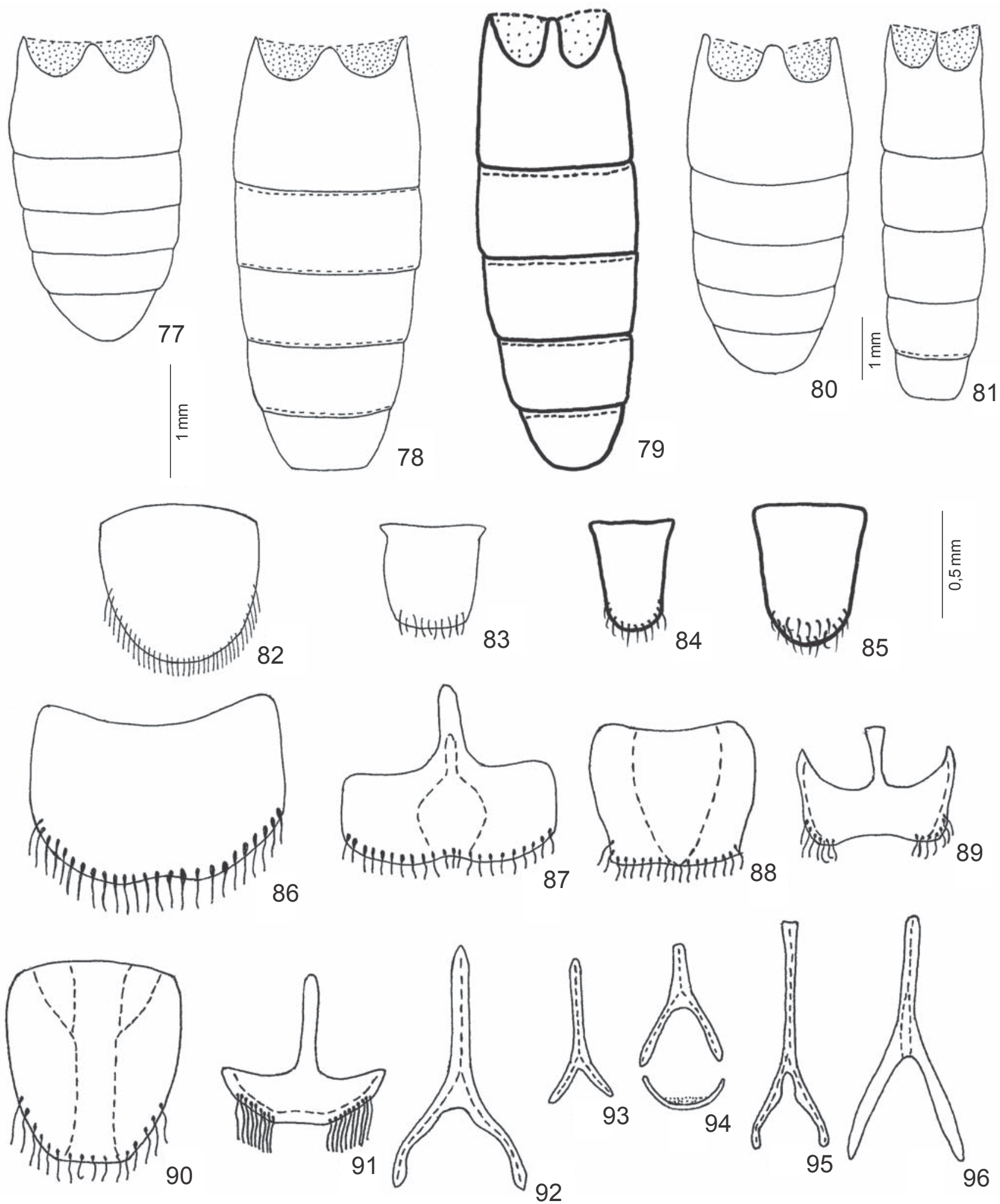

Figs. 77-96. 77-81. Abdomen: 77, Dihammaphora nigrovittata; 78, Dihammaphoroides sanguinicollis; 79, Pandrosos phtisicus; 80, Rhopalophora collaris; 81, Cleomenes auricollis. 82-85. Tergite VII, male: 82, Listroptera tenebricosa; 83, Dihammaphoroides sanguinicollis; 84, Pandrosos phtisicus; 85, Cleomenes auricollis. 86-91. Tergite and sternite VIII, male: 86,87, Listroptera tenebricosa; $\mathbf{8 8 , 8 9}$, Dihammaphoroides sanguinicollis; 90,91, Pandrosos phtisicus. 92-96. Dorsal and ventral arc: 92, Haenkea zischkai; 93, Dihammaphora nigrovittata; 94, Dihammaphoroides sanguinicollis; 95, Pandrosos phtisicus; 96, Cleomenes auricollis. Figs. 77-80, 82-96, respectively, in the same scale. 
Dihammaphoroides the surface is microrreticulate, lacking punctures, and glabrous.

The elytra of Pandrosos (Fig. 126) differ from all of the aforementioned genera, being narrow and elongate, weakly sinuous behind the middle and barely depressed; the surface is shinning, glabrous with coarse, dense punctures throughout; the dorsal costa is actually formed by one irregularly prominent interstice extending, at most, up to the middle of the elytra and, unlike the other Neotropical genera, the lateral costa occurs from behind the middle to the apical third making the epipelura vertical.

Wings. In Listroptera, Haenkea, Aguassay and Dihammaphora (Figs. 71, 72) the length of the apical part (from Radial cell to the wing apex) is about half the length of the basal part (from the wing base to the apex of the Radial cell); the cell of the Radius is open; the anal lobe is somewhat reduced; the base of the Radius $(\mathrm{R})$ presents a carinate area (ca); the arculus (arc) is well developed; the Sector vein (S), prior to the s-m, is conspicuous in Listroptera (Fig. 71), Haenkea and Aguassay, lacking in Dihammaphora (Fig. 72); the Anterior Sector (AS) and the s-m are sinuous; the Media $(\mathrm{M})$ is close to the Cubitus $(\mathrm{Cu})$, the distance between them subequal to $1 / 4$ of the s-m length; the basal section of the Anterior Media (AM) is missing; the Media (M) and the Plical (P) are reduced (the latter well developed in Aguassay); the Empusal (E) does not separate from the $1^{\text {st }}$ Anal (1A); except for Listroptera, the transverse $2 \mathrm{Aa}$ is diminishing or absent; the $\mathrm{E}+1 \mathrm{~A}$ is shorter than half the length of the $1 \mathrm{~A}+2 \mathrm{~A}$; the $2 \mathrm{Ab}$ is a little shorter than 2A; the Posterior Media (PM) plus the Cubitus form a strongly acute angle; the $\mathrm{MP}+\mathrm{CU}$ is elongate and sinuous and the Jugal $(\mathrm{Ju})$ reduced. The Sector and Plical veins are more reduced in Haenkea and Dihammaphora (Fig. 72).

The wing venation of these genera is similar to that of Rhopalophora with regard to the open cell of the Radius, the carinate area at the Radius base and the sinuous Anterior Sector vein. In addition, the apical part of the wing is developed and the anal lobe is moderately reduced. In Cleomenes (Fig. 75), the apical part of the wing is much shorter, the anal lobe is greatly reduced with reduction or even loss of the anal veins; the cell of the Radius is closed and large, the AS is straight and the base of $\mathrm{R}$ is not carinated.

Dihammaphoroides (Fig. 73) presents some other features. The apical part of the wings is short, as long as about $1 / 4$ of the length of the basal part; the cell of the Radius is closed and triangular, the r-s is oblique in relation to the Radius; the AS and s-m are straight, the latter vestigial; the S, AM, P, and all the anal veins are missing and the anal lobe is even more reduced than in Cleomenes. The only features in common with the other Neotropical genera are the arculus (arc) and the carinated area (ca) at the Radius base.

Pandrosos (Fig. 74) also differs from the previously mentioned genera. The wings are narrower with the apical part about $1 / 3$ as long as the basal part; the cell of the Radius is closed and triangular, the r-s is oblique in relation to the Radius and the Sector is missing; the AM is present and the $\mathrm{M}$ is reduced; the AS is not sinuous and the $\mathrm{s}-\mathrm{m}$ is arcuate; the Plical (P) is elongate and the Empusal (E) does not separate from the $1 \mathrm{~A}$; the transverse $2 \mathrm{Aa}$ is well defined and the $2 \mathrm{Ab}$ is half as long as $2 \mathrm{~A}$; the arculus and the carinated area at the Radius base are present. Radius cell closed and reduced and $2 \mathrm{Ab}$ half as long as $2 \mathrm{~A}$ are also observed in Rhinotragus (Fig. 76).

Legs. The legs of Haenkea, Dihammaphora, Aguassay, Timabiara and Listroptera (Figs. 118-124) are increasing in length, the hindlegs almost twice as long as the forelegs. The femora are pedunculate clavate, the peduncles sulcate and bicarinate, especially in Haenkea and Timabiara; the peduncles of the metafemora are greatly elongate, even twice as long as the club length; in Haenkea, Dihammaphora and Timabiara (Figs. 119-123) the metafemora are abruptly clavate and the clubs little longer than broad, while Listroptera and Aguassay (Figs. 118, 124) have gradually clavate metafemora with clubs almost as long as the peduncles; in all the genera the meso- and metafemora are acutely bidentate at the apex and the latter exceed the elytral apices by the club length (except some Dihammaphora species). The tibiae are cylindrical, somewhat impressed, weakly expanded apically, sulcate and carinate, especially the metatibiae; the tibial spurs are short, subequal in length. The metatarsi are about $1 / 3$ longer than the protarsi in Dihammaphora, Aguassay and Listroptera with the first segment as long as the following two combined; in Haenkea and Timabiara the metatarsi are twice as long as the protarsi and the first segment of the metatarsi, at least, 1/3 longer than the following two combined. Tarsal pads with short, compact, dense setae; in Listroptera, Timabiara and Dihammaphora, the first two tarsomera of all legs have a median glabrous vitta; in Haenkea, the glabrous vitta is absent from the protarsi. The empodium is reduced, without setae (Fig. 70).

The above features have also been observed in the Rhopalophorini (Fig. 129) (GIESBERT \& CHEMSAK 1993; MARQUES \& NAPP 1996, 2003; NAPP \& MARQUES 1999 a,b). In spite of the pedunculate, abruptly clavate femora, in Cleomenes (Figs. 127, 128) the legs are short; the femora peduncle is cylindrical, neither carinate nor sulcate and the metafemora do not reach the fifth urosternite; the tibiae are cylindrical, not carinate. Empodium reduced, without setae is observed in both Rhopalophora and Cleomenes.

In Dihammaphoroides (Fig. 125) the legs are short as in Cleomenes, but the femoral peduncle and the tibiae are carinate and/or sulcate. The hind legs are just $1 / 3$ longer than the forelegs and the metafemora reach the basal third of urosternite III. The tarsi are short, the metatarsi as long as the protarsi and the first segment of the metatarsi is shorter than the following two combined; the glabrous vitta occurs on the first two tarsomeres of the median and posterior legs and the empodium is also reduced, lacking setae.

In Pandrosos (Fig. 126) the hind legs are three times as long as the forelegs. The profemora are thicker and 

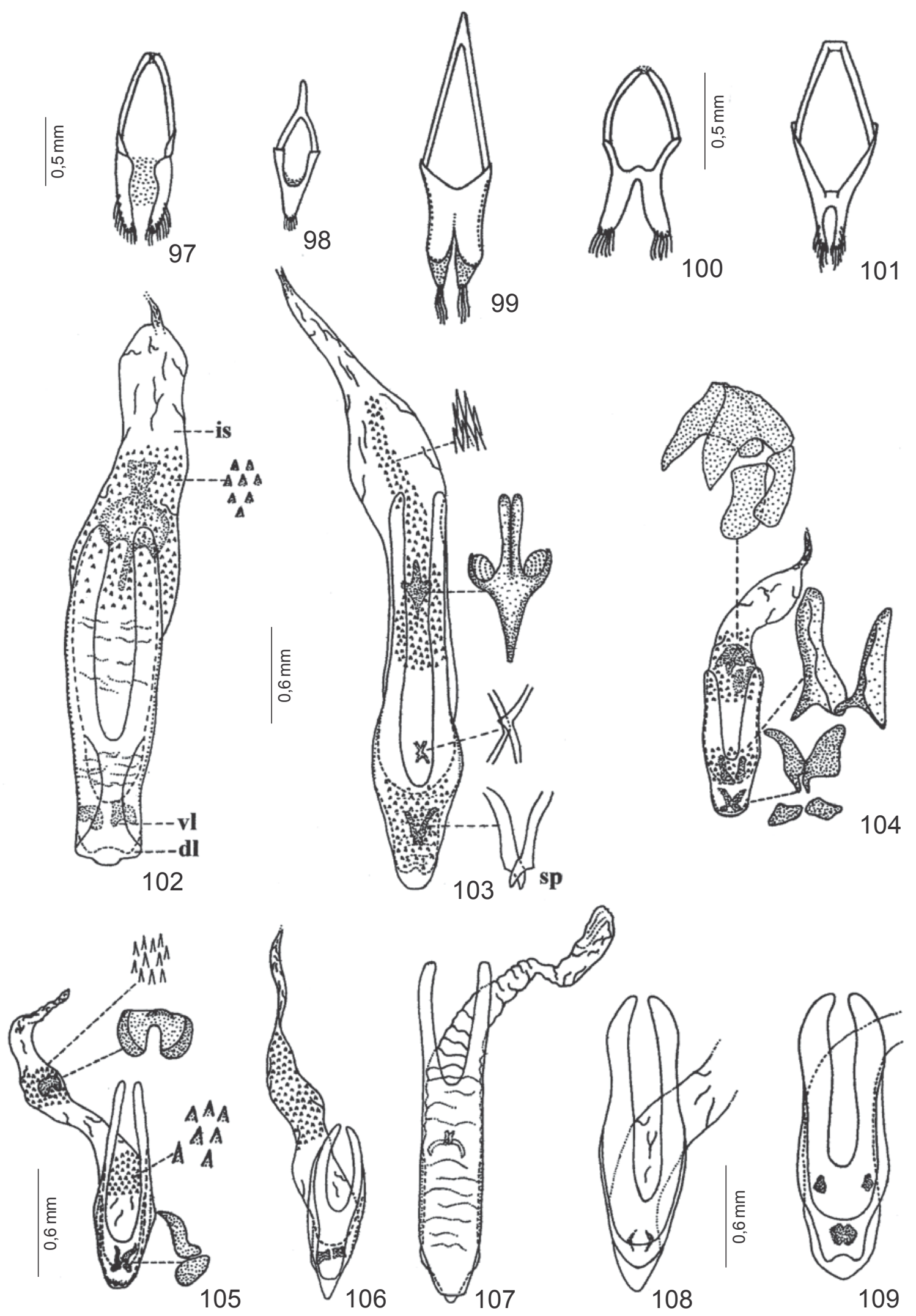

Figs. 97-109. 97-101. Tegmen: 97, Haenkea zischkai; 98, Dihammaphoroides sanguinicollis; 99, Pandrosos phtisicus; 100, Rhopalophora collaris; 101, Cleomenes auricollis. 102-109. Median lobe and internal sac: 102, Listroptera tenebricosa; 103, Haenkea atra; 104, Dihammaphora nigrita; 105, Dihammaphora nigrovittata; 106, Dihammaphoroides sanguinicollis; 107, Pandrosos phtisicus; 108, Cleomenes auricollis; 109, Rhopalophora collaris. $\mathrm{db}=$ dorsal lobe; is = internal sac; $\mathrm{sp}=$ sclerotized pieces; $\mathrm{vl}=$ ventral lobe. Figs.97-99, 100-101, 102-103, 104-106, 107109 , respectively, in the same scale. 


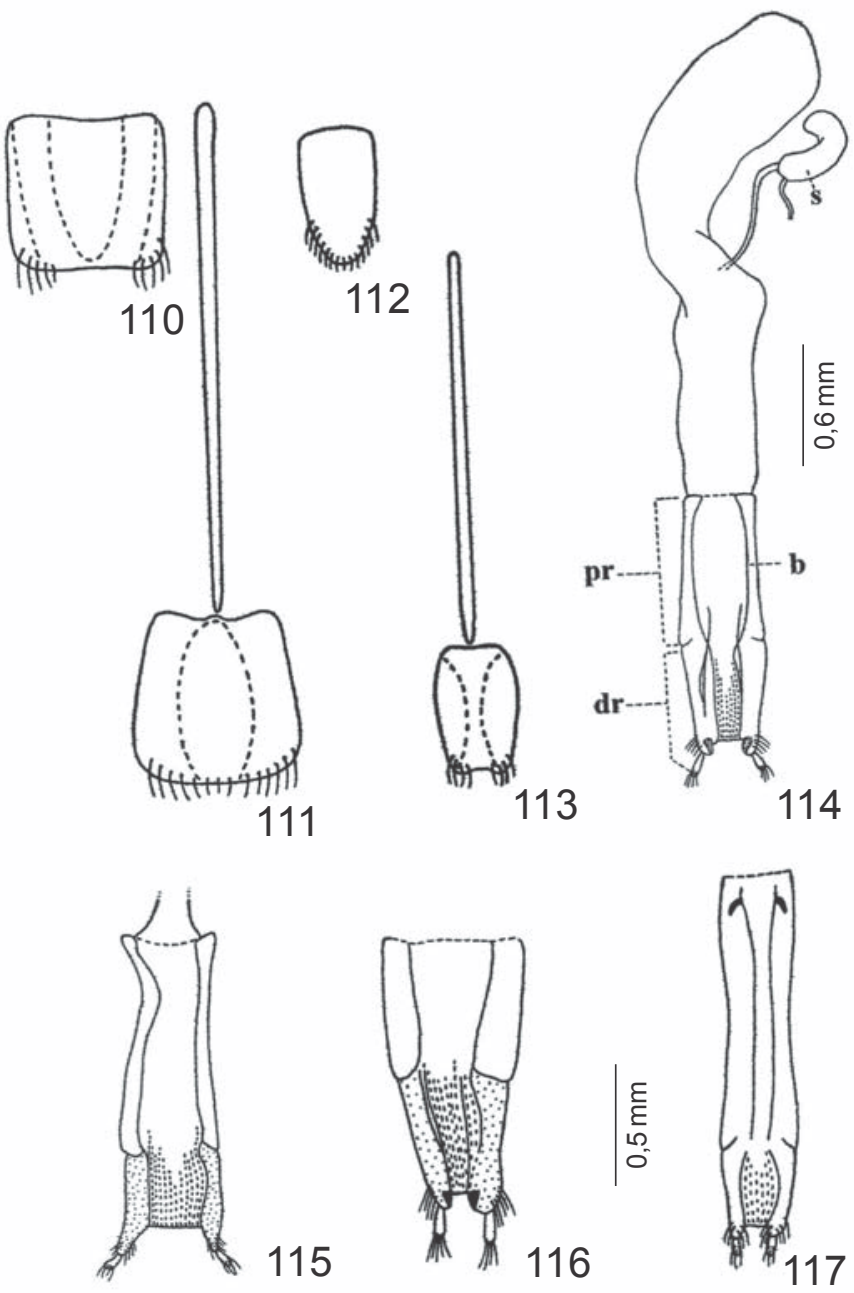

Figs. 110-117. Tergite and sternite VIII, female: 110, 111, Haenkea zischkai; 112, 113, Pandrosos phtisicus. 114-117. Ovipositor: 114, Haenkea zischkai; 115, Pandrosos phtisicus; 116, Rhopalophora collaris; 117, Cleomenes auricollis; $\mathrm{b}=$ baculli; $\mathrm{dr}=\mathrm{distal}$ region; pr=proximal region; s=spermatheca. Figs. 110-115, 116-117, respectively, in the same scale.

subcylindrical, while the meso- and metafemora are pedunculate clavate, with slender, cylindrical, neither carinate nor sulcate peduncle and all the femora are rounded apically; the metafemoral peduncle is elongate, twice as long as the club which is moderately enlarged; the metafemora reach or just exceed the elytral apices. The tibiae are cylindrical, slender, not carinate; the tibial spurs short and subequal in length. The metatarsi are about $1 / 3$ longer than the protarsi and the first segment of the metatarsi, at least, $1 / 3$ longer than the following two combined. The tarsal pads lack glabrous vittae and the pilosity is sparser than in the preceding genera. The empodium is also reduced and without setae.

\section{ABDOMEN}

In Listroptera, Aguassay, Haenkea, Timabiara and Dihammaphora the abdomen (Fig. 77) is similarly-shaped: oval, with the first urosternite, at least as long as the following two combined, the intercoxal process broad, rounded apically; urosternite $\mathrm{V}$ transverse, conspicuously convergent apically, rounded-truncate to feebly acuminate at apex; tergite VII (Fig. 82) as long as broad, the sides converging to the rounded apex.

Dihammaphoroides (Fig. 78) and Pandrosos (Fig. 79) differ in having an elongate, cylindrical abdomen; urosternite I shorter than the following two combined, the intercoxal process broad in Dihammaphoroides and narrow in Pandrosos; urosternite $\mathrm{V}$ transverse, weakly convergent apicad, the apex truncate in Dihammaphoroides and rounded in Pandrosos; in the former, the tergite VII (Fig. 83) is about as broad as long, subparallel at the sides and rounded truncate at the apex, while in Pandrosos (Fig. 84) it is narrow, elongate, almost 1.5 times as long as broad and slightly convergent to the rounded apex.

Cleomenes (Fig. 81) differs from all the Neotropical genera by the cylindrical, elongate abdomen with more or less quadrangular urosternites; the first urosternite is somewhat narrowed at the base, the intercoxal process is very narrow between the metacoxae and tergite VII is elongate, about 1.5 times as long as broad, with sides converging at the apical half, the apex rounded.

The abdominal shape of Listroptera, Aguassay, Haenkea, Timabiara and Dihammaphora is, in all aspects, similar to that of Rhopalophora (Fig. 80). Even Dihammaphoroides (Fig. 78) has an abdomen more like Rhopalophora.

Pandrosos (Fig. 79) has some similarities with Rhinotragus with the first urosternite narrowed at base, with a short intercoxal process between the somewhat rounded, subcontiguous metacoxal cavities and the narrow, elongate tergite VII (Fig. 84).

Male genitalia. All parts of the male genitalia are similar in Listroptera, Aguassay, Haenkea and Dihammaphora: tergite VIII (Fig. 86) is transverse with small differences in the apex (sinuate in Listroptera and Aguassay), sides (subparallel in Listroptera and rounded in Haenkea) and among the examined Dihammaphora species. In all the genera sternite VIII (Fig. 87) is transverse, subparallel at the sides, bisinuate at the apex and the sternal apophysis is shortened. The ventral arc is fork-shaped (Fig. 92, 93), almost as long as the tegmen, the arms forming an acute angle (except in Haenkea) and the bifurcate part is about as long as the apophysis (shorter in $D$. nigrovittata, Fig. 93). The dorsal arc is missing. Tegmen (Fig. 97): distal region entirely divided into lateral lobes joined by a membranous area; the ring piece is somewhat rounded and convergent with the lateral arms not fused apically, but linked by the sheath of the ring piece. The median lobe (Figs. 102105 ), in general, has the apical region about half as long as the basal apophyses (except Dihammaphora nigrovittata, Fig. 105); dorsal lobe is slightly longer than the ventral lobe, enlarged at the median foramen then narrowed apicad; apex rounded (truncate in Listroptera and D. marginicollis, in which the dorsal lobe is feebly enlarged); the ventral lobe is sinuate at the apex. The internal sac is from moderately long to 1.5 
times as long as the median lobe; the armature consisting of one or two spiculate areas and one pair of sclerotized pieces, asymmetrical or not, at the apical region plus a median, strongly sclerotized and well developed piece provided or not with lateromedian projections. The armature varies among the Dihammaphora species: D. nigrita and D. nigrovittata (Figs. 104-105) have two apical pairs of sclerotized pieces, while $D$. marginicollis has one pair; medially, there are two pairs of developed, sclerotized pieces in D. nigrita (Figs. 104) and only one pair in the other two examined species.

With regard to the male genitalia, the only similarity with Cleomenes (Fig. 108) is in the shape of the median lobe, but is also observed in Rhopalophora (Fig. 109). Several other characters that distinguish the Neotropical genera from Cleomenes were observed in Rhopalophora and have been recorded to occur also in other Rhopalophorini genera (MARques \& NAPP 1996, 2003; NAPP \& MARques 1999 a,b). The internal sac with armature corroborates Fragoso (1978) and the tergite VIII broader than long, the ring piece of the tegmen rounded and not fused apically, the ventral arc as long as the tegmen and the ventral lobe of the median lobe bifid at the apex, were considered the synapomorphic conditions within the Rhopalophorini (MARQues \& NAPP 2003). The study of EHARA (1954), who examined the male genitalia of Dere thoracica, corroborates the differences of other Cleomenini in relation to the Neotropical genera.

The male genitalia of Dihammaphoroides is quite different from the above: tergite VIII (Fig. 88) is about as long as broad, narrowed near the apex which is truncate; sternite VIII (Fig. 89 ) is somewhat convergent apicad, emarginate at the apex; the apophysis is narrowed medially, truncate at the apex. The ventral arc (Fig. 94) is shortened, half as long as the tegmen, the bifurcate part longer than the apophysis. The dorsal arc is present (Fig. 94). The apical region of the tegmen (Fig. 98) is not divided into lobes, narrowed apicad and the apex is rounded; the ring piece is convergent, fused from the subdistal portion, weakly geniculate at the widest portion. The apical region of the median lobe (Fig. 106) is almost as long as the basal apophyses; the dorsal lobe is much shorter than the ventral, narrowed after the median foramen, rounded at the apex; the ventral lobe is acuminate at the apex. The internal sac is short with a pair of sclerotized pieces at the apical part and largely spiculate at the distal half.

Pandrosos has: tergite VIII (Fig. 90), at least 1.5 times as long as broad, slightly convergent at the sides, truncate at the apex; sternite VIII (Fig. 91) much shorter than the tergite, strongly transverse with the sides converging apicad, the apex truncate; sternal apophysis 1.5 times as long as the sternite, rounded at apex. Ventral arc (Fig. 95) with the bifurcate part half as long as the apophysis which is truncate at the apex. The dorsal arc is missing. The tegmen (Fig. 99) is narrow and elongate, the apical region divided into lobes from the middle, the lobes attenuate apically; the ring piece is convergent, acuminate, fused apically. The median lobe (Fig. 107) is parallel sided, the basal apophyses are short, with about $1 / 3$ of the median lobe's length; dorsal and ventral lobes are similarly- sized, respectively truncate and acuminate at apex. The internal sac has one pair of sclerotized pieces closer to the median foramen, lacking spiculated areas. Tergite VIII, median lobe and ventral arc are very similar to those of Rhinotragus and Tomopterus Audinet-Serville, 1833 (Magno 1994) (Rhinotragini).

Female genitalia. Listroptera, Aguassay, Haenkea and Dihammaphora are very similar in the structures of the female genitalia. Segment VIII (Figs. 110, 111) is as long as broad, subparallel at the sides, almost entirely membranous; the tergite is truncate to sinuous at the apex, the sternite truncate; the sternal apophysis is about twice as long as the sternite in Listroptera and Aguassay, and about 3 times as long in Haenkea (Fig. 111) and Dihammaphora. The ovipositor (Fig. 114 ) is membranous, somewhat shortened, about twice as long as broad in Listroptera, Aguassay and Dihammaphora, and 3 times as long in Haenkea; the distal section is shorter than the proximal section; the bifid apical portion is appendiciform bearing a sclerotized area on the inner side of each lobe; styli are cylindrical, apically inserted; dorsal baculli are about $1 / 3$ shorter than the ventral baculli. The spermatheca is reniform in Haenkea, Aguassay and Dihammaphora; a little longer and curved only at the apex in Listroptera; the spermathecal gland is as long as or little shorter than the spermatheca. Apodemes at the oviduct base and symbiont-containing pouches are missing. This kind of genitalia is similar to that observed in Rhopalophora (Fig. 116) and other Rhopalophorini genera (MARQues \& NAPP 1996; 2003), mainly in relation to the distal and proximal sections of the ovipositor which are short and subequal in length. This condition was considered a synapomorphy of the clade Rhopalophora + , within the Rhopalophorini (MARQUES \& NAPP 2003), differing from Cleomenes (Fig. 117) in which the proximal section of the ovipositor is very elongate.

Pandrosos has: segment VIII (Figs. 112, 113) elongate, subparallel at the sides, the apex truncate; sternal apohysis about 2.5 times as long as the sternite. The ovipositor (Fig. 115 ) with the proximal section twice as long as the distal section, the bifid apical portion with long, narrow lobes; ventral baculli are half as long as the dorsal baculli; spermatheca somewhat elongate, curved only at the apex. Apodemes at the oviduct base and symbiont-containing pouches are missing.

\section{DISCUSSION AND CONCLUSIONS}

The results show that the the Neotropical genera presently included in the Cleomenini are not a homogeneous group. The same was observed in the examined Oriental and Afrotropical genera and corroborated by the literature (GressitT \& Rondon 1970). The weak delimitation between Rhopalophorini and Cleomenini, as given by LACORDAIRE (1869), together with the liable features used to characterize the latter (e.g. antennae variable in shape, shorter or little longer than the body; anterior coxal cavities open or closed behind; femora with an elongate peduncle or only narrowed at the base plus 


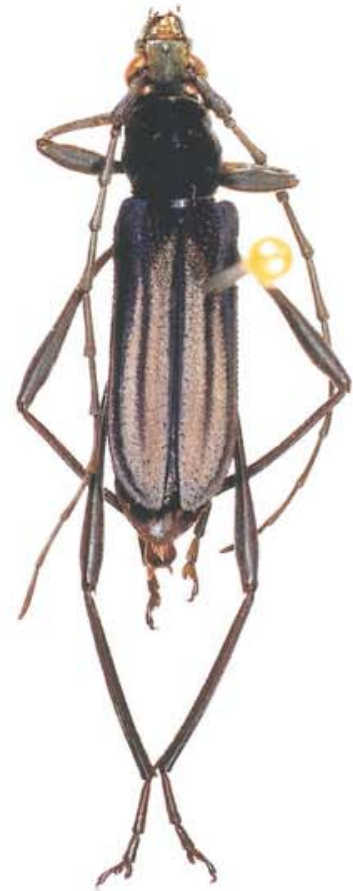

118

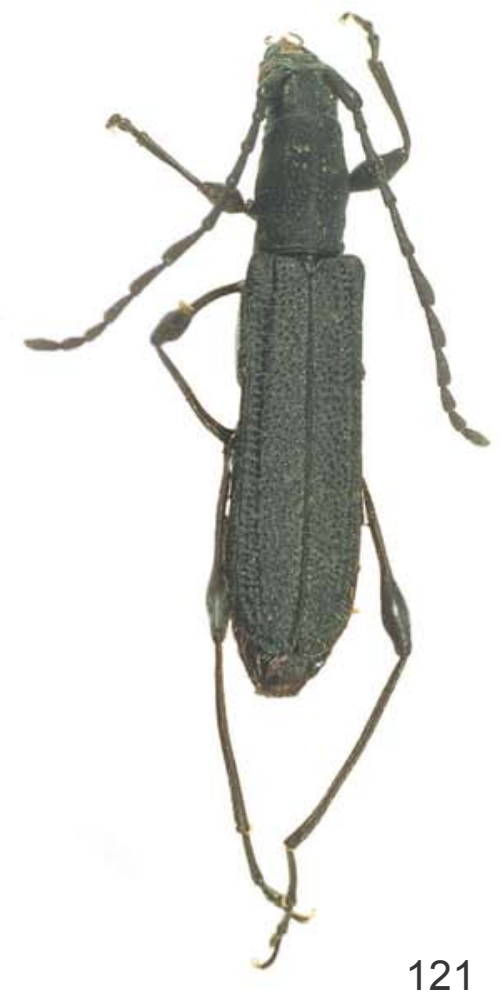

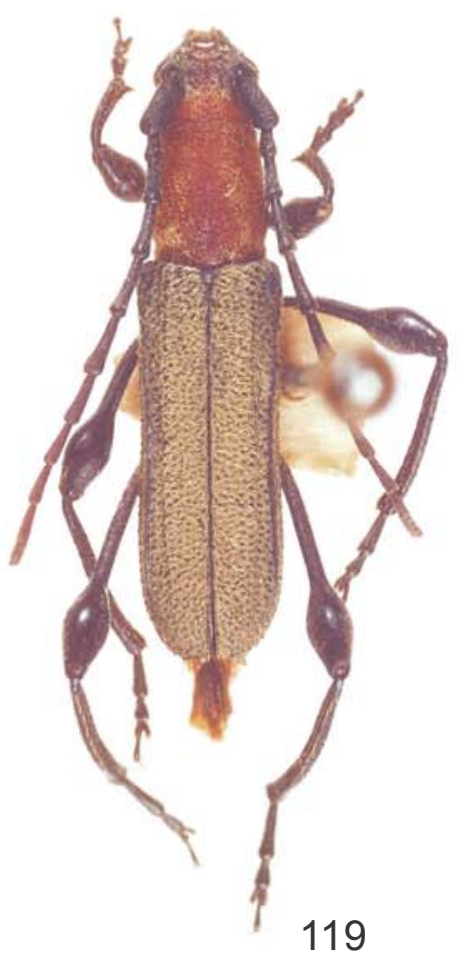

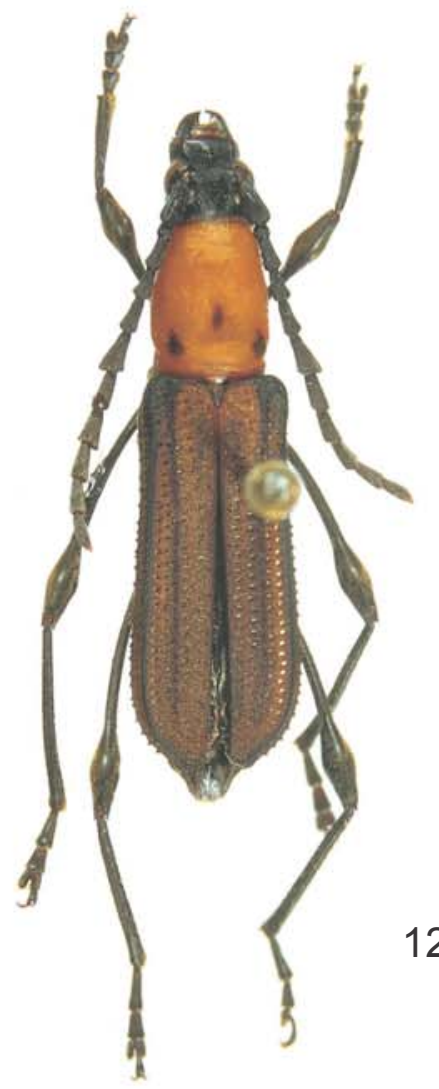

120
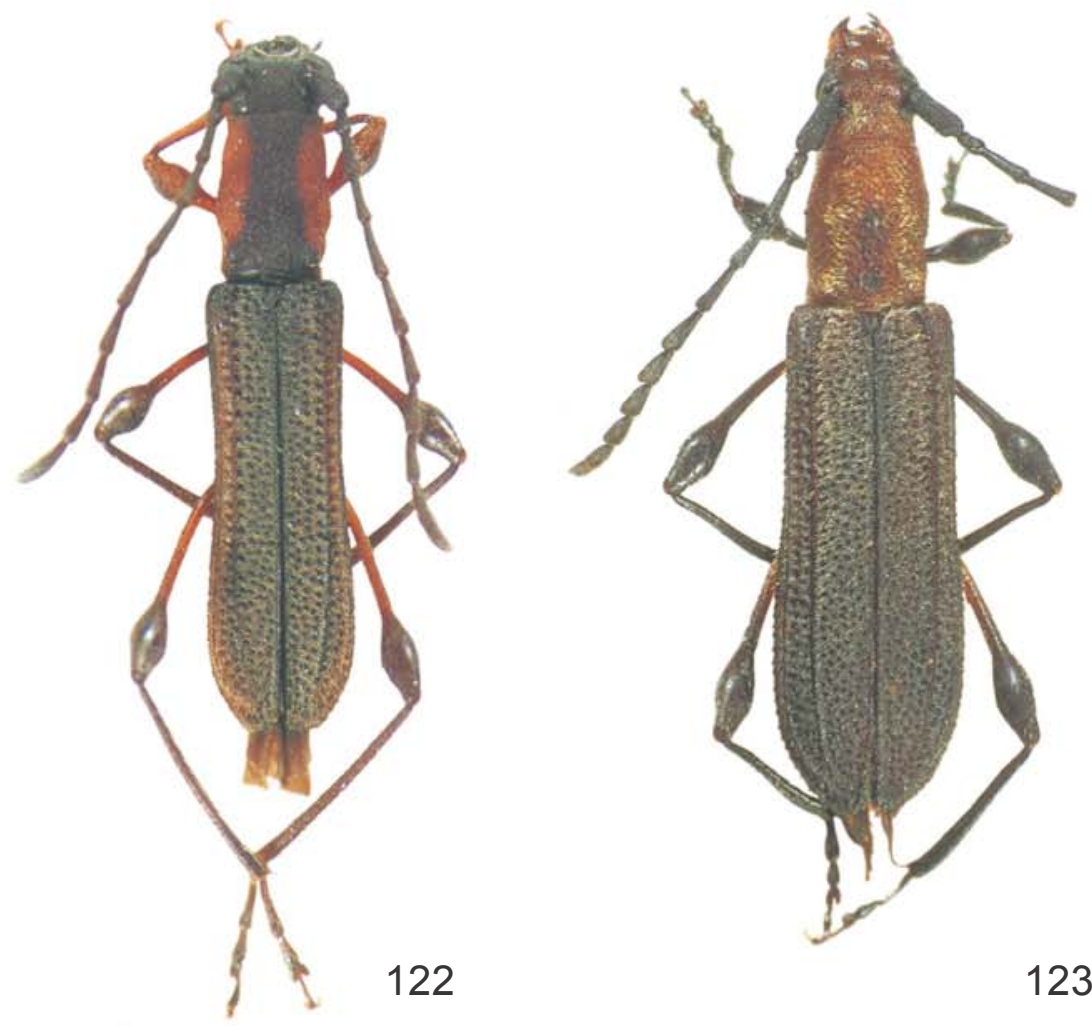

123

Figs. 118-123. 118, Listroptera tenebricosa; 119, Timabiara bahiensis; 120, Haenkea zischkai; 121, Dihammaphora nigrita; 122, Dihammaphora marginicollis; 123, Dihammaphora nigrovittata. 


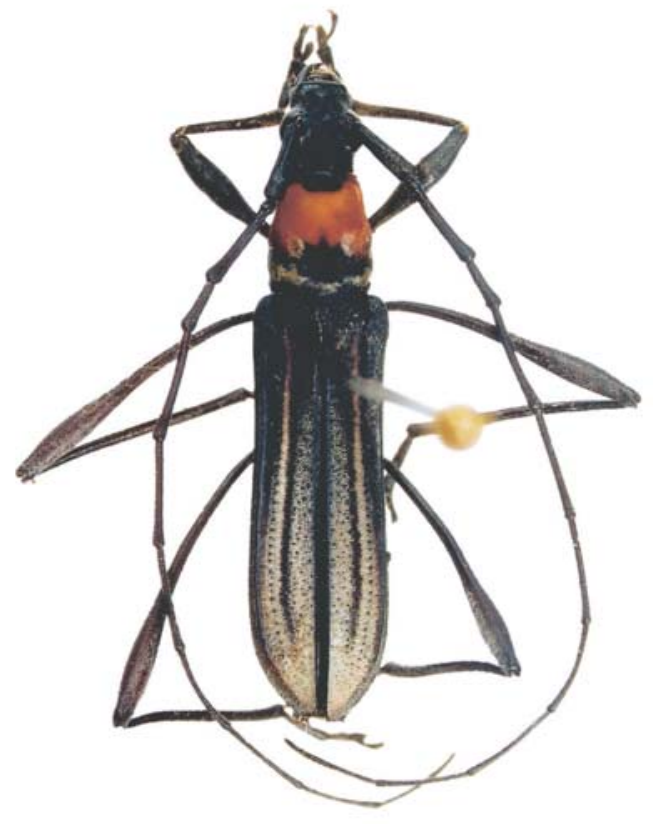

124

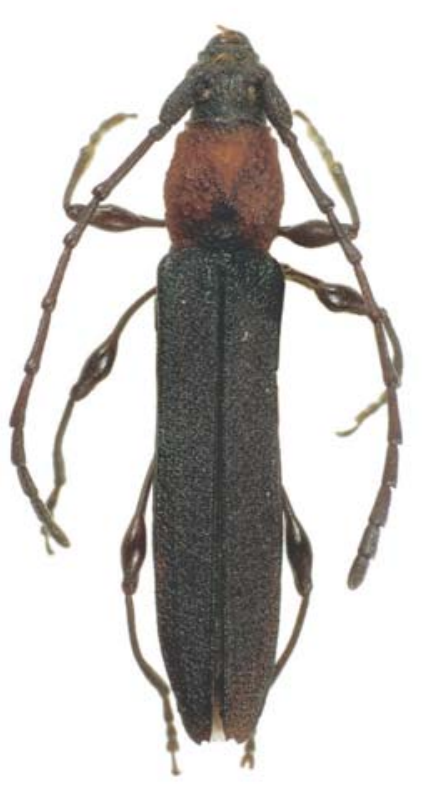

125
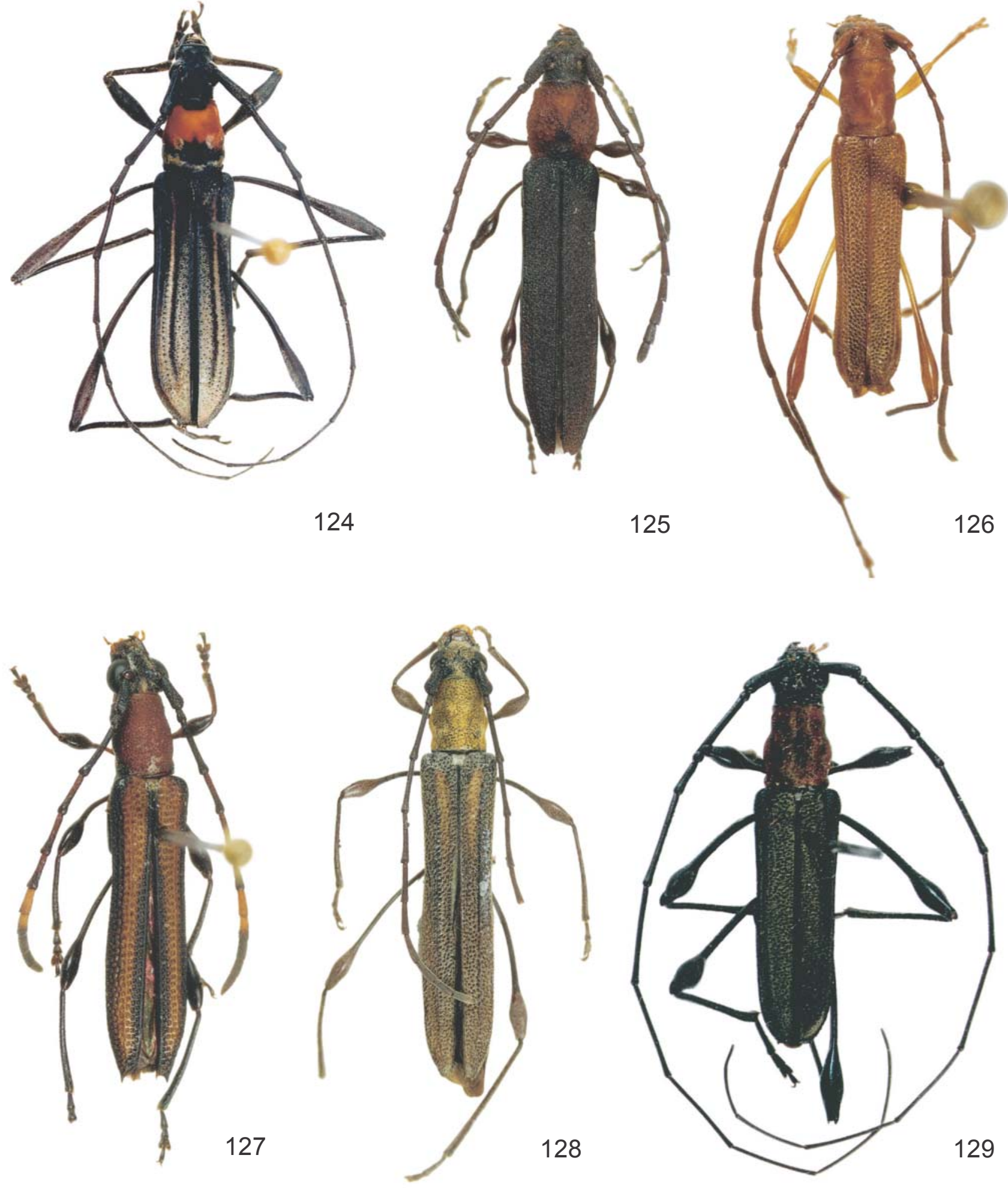

Figs. 124-129. 124, Aguassay collaris; 125, Dihammaphoroides sanguinicollis; 126, Pandrosos phtisicus; 127, Cleomenes dihammaphoroides; 128, C. auricollis; 129, Rhopalophora collaris. 
different kinds of clubs, etc.) seems to have caused subsequent authors to include similar genera in different tribes and viceversa. Among the Oriental and Afrotropical Cleomenini genera it was possible to observe, for example, that Apiogaster Perroud, 1855 has several features of the Rhinotragini, and Artimpaza Thomson, 1864 is very similar to Closteropus (Rhopalophorini); the shape of the head, pro- and mesocoxae, intercoxal process of the pro- and mesosternum and elytra of Procleomenes Gressit \& Rondon, 1970 are similar to those of Ozodes Audinet-Serville, 1834 and Neozodes Zajciw, 1958 (Neotropical Necydalopsini) (MARQues \& NAPP 2003). The only feature shared by Dere White, 1855 and Cleomenes is the antennal shape. In general, these genera differ from both Cleomenes and the Neotropical Cleomenini.

Among the Neotropical Cleomenini, Listroptera, Haenkea, Timabiara, Dihammaphora and Aguassay (Figs. 118-124) form a homogeneous group as previously noticed by NAPP \& Mermudes (2001 a, b). The present study shows that, besides some features of the antennae, they do not have more similarities with Cleomenes or any other Cleomenini. Some characters that occur in those genera and Cleomenes have also been recorded in Rhopalophora and other Rhopalophorini genera (MARQues \& NAPP 1996, 2003; NAPP \& MARQuES 1999 a, b). It was also demonstrated that the genera mentioned above share several synapomorphies of the Rhopalophorini and/or its groupings as defined by MARQues \& NAPP (2003), such as: 1) head rostrated, the genae and clypeus elongate (Figs. 1-7, 10); 2) eyes deeply emarginate, the upper margin of the lower lobes and the portion joining the upper and lower lobes placed far from the antennal alveolus (Figs. 6-7, 10); 3) mouthparts: galea strongly enlarged and obliquely truncate at apex; first segment of the maxillary palpi as long as the apical, $2^{\text {nd }}$ and $3^{\text {rd }}$ segments short, conical (Figs. 21, 24);4) endosternites: proendosternite quadrangular, entirely fused along middle (Figs. 55, 58); metendosternite with the lateral lamina and arms fused, the peduncle entirely fused to the inner wall of the metasternum (Figs. 63, 64); 5) intercoxal process of mesosternum broader than the coxal cavity, juxtaposed and strongly connected to the equally broad anterior projection of metasternum (Figs. 38, 39, 43); 6) wings: Radius with a carinate area at the base (Fig. 71); 7) legs: femoral peduncles and tibiae sulcate and carinate, the metafemora elongate and the tibiae impressed; 8) genitalia: shape of the ring piece of the tegmen (Figs. 97, 100) and ovipositor with the proximal section shortened (Figs. 114, 116).

Another set of characters not mentioned by MARQuES \& NAPP (2003) gives additional support to the hypothesis of closer relationship of the group formed by Dihammaphora, Haenkea, Timabiara, Aguassay and Listroptera with Rhopalophora: 1) eyes sinuous at posterior margin, the lower ocular lobe transverse, moderately large (Figs. 6, 7, 10; 2) Radius cell open, s-m missing (Fig. 71); 3) metepisternum broad, plane and evenly sclerotized throughout (Figs. 44, 45); 4) abdomen oval; first urosternite as long as the following two combined, the intercoxal projection broad, rounded apically (Figs. 77, $80)$; 5) male genitalia: tegmen shortened, as long as the ventral arc; internal sac of median lobe with armature (Figs. 92-93, 102-105).

Therefore, the transference of that group of genera from Cleomenini to Rhopalophorini seems to be well established. It may be possible that they constitute a group within the Rhopalophorini mainly by the shape of both the elytra and the antennae plus some features of the mouthparts and wings. It must be noticed that some of the genera presently assigned to Rhopalophorini have either gradually clavate femora (Muxbalia Giesbert \& Chemsak, 1993), similar to those of Listroptera and Aguassay (Figs. 118, 124) or short, subserrate antennae (Rhopalina Monné, 1989).

The affinities of Dihammaphoroides (Fig. 125) were not clearly established since it has morphological similarities with both Cleomenes and the group mentioned above, besides some proper features. It is similar to Cleomenes by: 1) antennae with segments 3 to 5 elongate, the following segments shortened and expanded apically; 2) elytra elongate and subparallel at sides; 3) legs short, the femora reaching the middle of the third urosternite; 4) intercoxal process of mesosternum narrower than the coxal cavity and notched at apex to fit into the metasternum (Figs. 40, 42); 5) wing venation and anal lobe reduced, the apical part of the wings shortened (Figs. 73, 75); 6) abdomen elongate (Figs.78, 81); 7) the internal sac of the median lobe lacking armature (Fig. 106). But, unlike Cleomenes, in Dihammaphoroides, the antennal segments are bicarinate and sulcate and the fourth segment is short; the elytra are flattened, costate laterally and the epipleurae vertical; and the femoral peduncles and all tibiae are sulcate and/or carinate.

On the other hand, Dihammaphoroides also has many similarities with the group formed by Dihammaphora, Haenkea, Timabiara, Aguassay and Listroptera such as: the shape of the head, maxillary palpi, galea and eyes, the latter two defined as synapomorphies of the Rhopalophorini (Marques \& Napp 2003); antennal segments bicarinate on the dorsal and ventral sides; prothorax slightly, regularly rounded at the sides, the procoxal cavities and the prosternal process (Fig. 34) similar to those of Listroptera, the latter very different from that of Cleomenes (very narrow and strongly expanded only at the apex, Fig. 37); metepisternum broad, plane, evenly sclerotized ventrally below the carina and dorsally above the carina (Fig. 45); metendosternite with lateral arms and lamina fused (Fig. $65)$, the peduncle fused to the inner wall of the metasternum; elytra dorsally flattened, impressed near the scutellum and costate above the vertical epipleurae; presence of a carinate area at the Radius vein base (Fig. 73); femoral peduncles and tibiae carinate and/or sulcate.

Although it was not possible, at this time, to clearly define the affinities of Dihammaphoroides, it seems that this genus is anatomically more like the Neotropical genera and, so, it is tentatively included in the Rhopalophorini. Nevertheless, further studies are required to clarify the assignment of Dihammaphoroides. A possible transference to another Neotropical Cerambycinae tribe shoud be taken into consideration in future revisionary studies. 
Pandrosos (Fig. 126) in addition to having no affinities with the preceding genera, presents several features of the Rhinotragini: 1) head with an elongate rostrum, flattened dorsally and shortened behind the eyes (Fig. 8); 2) eyes very large, prominent, proximate on the frons, the portion linking the lobes even broader than the upper lobe; 3 ) some aspects of the labrum, mandibles and labium as shown in Figs. 13, 18, $27,30 ; 4)$ antennae with segments 3 to 5 cylindrical elongate, the following segments thickened and subserrate (Fig. 126); 5) proendosternite cylindrical, finger-like, not fused medially (Fig. 57); 6) pro- and mesosternal intercoxal process narrow (Figs. 35, 41); 7) pro- and mesocoxae globose, exserted and subcontiguous; 8) metasternum somewhat swollen, metepisterna narrowed behind (Figs. 41, 46); 9) wing venation (Fig. 74); 10) abdomen elongate cylindrical, narrowed at base, the intercoxal process of the first urosternite short and narrow, the metacoxal cavities large, subcontiguous (Fig. 79); 11) male genitalia: tergite VIII elongate, median lobe parallel-sided with short apophyses and lacking armature (Figs. 84, 107). Rhinotragini is one of the largest and most diversified tribes of Cerambycinae, and Pandrosos resembles some species of Ommata White, 1855, by having clavate femora, antennae longer than the body with distal segments subserrate and entire elytra. Therefore, Pandrosos is tentatively returned to the Rhinotragini, corroborating BATES $(1867,1870)$ who originally placed the genus into this tribe.

The studied species of Dihammaphora (Figs. 121-123), presented some anatomical differences. For example, the head shape, the number of antennal segments, procoxal cavities (open/closed behind), elytral costae and male genitalia, indicate that the genus must be revised.

\section{Rhopalophorini Blanchard, 1845}

\section{Listroptera Audinet-Serville, 1834. New placement. Dihammaphora Chevrolat, 1859. New placement. Haenkea Tippmann, 1953. New placement. \\ Timabiara Napp \& Mermudes, 2002. New placement. Aguassay Napp \& Mermudes, 2002. New placement. Dihammaphoroides Zajciw, 1967. New placement.}

\section{Rhinotragini Thomson, 1864}

\section{Pandrosos Bates, 1867. Reinstated placement.}

\section{Cleomenini Lacordaire, 1869}

\section{With no representatives in the New World.}

Aknowledgments. We thank Dr. Miguel A. Monné (Museu Nacional, UFRJ, Brazil), Dr. Ubirajara R. Martins (Museu de Zoologia, USP, Brazil) and Dr. Charles Bellamy (Transvaal Museum, South Africa) for the loan of the studied specimens and Dr. Albino M. Sakakibara (Departamento de Zoologia, Universidade Federal do Paraná) for the revision of the English version of the manuscript and for taking the photographs. To CAPES and CNPq for financial support.

\section{REFERENCES}

Audinet-Serville, J. G. 1834. Nouvelle classification de la famille des longicornes (suite). Annales de la Société Entomologique de France 3(1): 5-110.

Aurivillius, C. 1912. Coleopterorum Catalogus, pars 39, Cerambycidae, Cerambycinae. Berlim, W. Junk, 574 p.

Bates, H. W. 1867. New genera of longicorn Coleoptera from the river Amazons. The Entomologist's Monthly Magazine 4: 22-28.

Bates, H. W. 1870. Contributions to an insect fauna of the Amazon Valley (Coleoptera, Cerambycidae). Transactions of the Royal Entomological Society of London 1870: 391-444.

Bates, H. W. 1873. Notes on the Longicorn Coleoptera of Tropical America. The Annals and Magazine of Natural History, ser. 4, 11: 117-132.

BlackWELDER, R. E. 1946. Checklist of the coleopterous insects of Mexico, Central America, the West Indies and South America. Part 4. Bulletin of the United States National Museum 185: 551763.

Chevrolat, L. A. 1859. Description d'un genre nouveau établi aux dépens de plusieurs espèces de Rhopalophora de Dejean. Arcana Naturae 1: $50-54$.

Di IoRIo, O. I. 1994. Cerambycidae (Coleoptera) y plantas hospedadoras del Noroeste de Argentina. Revista Brasileira de Entomologia 38(1): $15-22$.

Di Iorio, O. I. 1997. Plantas hospedadoras y biogeografia de Cerambycidae (Coleoptera) del noroeste y centro de la Argentina. Revista de Biologia Tropical 44(3)/45(1): 149-158.

Ehara, D. 1954. Comparative anatomy of male genitalia in some Cerambycid beetles. Journal of the Faculty of Science, Hokkaido University, Zoology 12(6): 61-114.

Fragoso, S. A. 1978. Male and Female genitalia as a basis for tribal classification of the subfamily Cerambycinae of America North of Mexico (Cerambycidae, Coleoptera). Tese de Doutorado. Florida University, Florida, 92 p.

Fragoso, S. A. 1980. Diaphanous preparations from dark, opaque Coleopterans. Coleopterists Bulletin 34(2): 143-144.

Giesbert, E. F. \& J. A. Chemsak.1993. A Review of the Rhopalophorini (Coleoptera: Cerambycidae) of North and Central America. Insecta Mundi 7(1-2): 27-64.

Gounelle, E. 1911. Liste des Cérambycides de la région de Jatahy, Etat de Goyaz, Brésil. Annales de la Société Entomologique de France: 103-252.

Gressitt, J. L. 1951. Longicorn beetles of China. Longicornia 2: 1667.

Gressitt, J. L. \& J. A. Rondon. 1970. Cerambycids of Laos (Disteniidae, Prioninae, Philinae, Aseminae, Lepturinae, Cerambycinae). Pacific Insect Monograph 24: 1-314.

Lacordaire, J. T. 1869. Histoire Naturelle des Insectes. Genera des Coléoptères. Paris, Librairie Encyclopediqyue de Roret, 8: 1-552; 9: 1-409.

Magno, P. R. 1994. Sistemática e Zoogeografia do gênero Tomopterus Audinet-Serville, 1833 (Coleoptera, Cerambycidae, Cerambycinae, Rhinotragini). Tese de Mestrado. Rio de Janeiro, Universidade Federal do Rio de Janeiro, $220 \mathrm{p}$.

Marques, M. I. 1998. Análise cladística da tribo Rhopalophorini Blanchard, 1845 (Coleoptera, Cerambycidae, Cerambycinae). Tese de Doutorado. Curitiba, Universidade Federal do Paraná, xi +161 p.

Marques, M. I. \& D. S. NAPp, 1996. Revisão e transferência para Rhopalophorini (Coleoptera, Cerambycidae, Cerambycinae) dos gêneros Coremia A.-Serville, 1834 e Merocoremia Marques, 1994. Revista Brasileira de Entomologia 40(3/4): 379-423.

Marques, M. I. \& D. S. NAPP. 2003. Análise cladística da tribo Rhopalophorini Blanchard, 1845 (Coleoptera, Cerambycidae, Cerambycinae). Revista Brasileira de Entomologia 47(4): 491545 .

Mermudes, J. R. M. 1998. Nova espécie de Dihammaphora Chevrolat, 
1859 da Colômbia (Coleoptera, Cerambycidae, Cerambycinae, Cleomenini). Iheringia, Série Zoologia, 87: 81-86.

Mermudes, J. R. M. 1999. Morfologia comparada dos gêneros neotropicais de Cleomenini Lacordaire, 1869 (Coleoptera, Cerambycidae, Cerambycinae). Tese de Mestrado. Curitiba, Universidade Federal do Paraná, xii +89 p.

Mermudes, J. R. M. \& D. S. NAPP. 2000. Review of the genus Haenkea Tippmann (Coleoptera, Cerambycidae, Cerambycinae, Cleomenini). Coleopterists Bulletin 54(4): 511-519.

Mermudes, J. R. M. \& D. S. Napp. 2001. Revision of Eupempelus Bates and its transference to Heteropsini Lacordaire (Coleoptera, Cerambycidae, Cerambycinae). Revista Brasileira de Zoologia 18(1): 245-253.

Mermudes, J. R. M. \& D. S. Napp. 2002. Redescrição e transferência do gênero Fregolia Gounelle, 1911 para Callidiopini (Coleoptera, Cerambycidae). Revista Brasileira de Entomologia 46(4): 553 559 .

Monné, M. A. 1993. Catalogue of the Cerambycidae (Coleoptera) of the Western Hemisphere. Part IX. São Paulo, Sociedade Brasileira de Entomologia, $131 \mathrm{p}$.

Monné, M. A. 1994. Catalogue of the Cerambycidae (Coleoptera) of the Western Hemisphere. Part X. São Paulo, Sociedade Brasileira de Entomologia, $81 \mathrm{p}$.

Monné, M. A. \& E. F. Giesbert. 1994. Checklist of the Cerambycidae and Disteniidae (Coleoptera) of the Western Hemisphere. Burbank, Wolsfgarden Books, xiv+409 p.

NAPP, D. S. 1994. Phylogenetic relationships among the subfamilies of Cerambycidae (Coleoptera, Chrysomeloidea). Revista Brasileira de Entomologia 32(2): 265-419.

Napp, D. S. \& M. I. Marques. 1999a. Gurubira, a new genus of Rhopalophorini (Coleoptera, Cerambycidae). Revista Brasileira de Entomologia 43(1/2): 35-45.

NAPP, D. S. \& M. I. MARques. 1999b. Revision of the genus Ischionodonta Chevrolat, 1859 (Coleoptera, Cerambycidae). Revista Brasileira de Entomologia 43(1/2): 109-130.

Napp, D. S. \& J. R. M. Mermudes. 1999. Taxonomic studies on Compsocerini and tribal reassignment of Stenochariergus Giesbert and Hovore (Coleoptera, Cerambycidae). Coleopterists Bulletin 53(1): 80-86.

Napp, D. S. \& J. R. M. Mermudes. 2001a. Revision of the genus Listroptera Audinet-Serville and description of Aguassay, new genus (Coleoptera, Cerambycidae, Cleomenini). Coleopterists Bulletin 54(1): $1-9$.

Napp, D. S. \& J. R. M. Mermudes. 2001b. New South American genus and species of Cleomenini (Coleoptera, Cerambycidae). Revista Brasileira de Zoologia 18 (supl.1): 61-66.

SaAlas, U. 1936. Über das Flügelgeäder und die phylogenetische Entwicklung der Cerambyciden. Annales Zoologici Societatis Vanamo 4(1): 1-198.

Tavakilian, G.; A. Berkov \& B. Meurer-Grimes. 1997. Neotropical tree species and their faunas of xylophagous longicorns (COLEOPTERA: CERAMBYCIDAE) in French Guiana. The Botanical Review 63(4): 303-355.

Tippmann, F. F. 1953. Studien über neotropische longicorner (Coleoptera, Cerambycidae). Dusenia 4: 181-228.

THOMson, J. 1860. Essai dúne classification de la familie des cérambycides et matériaux pour servir a une monographie de cette famille. Paris, $404 \mathrm{p}$.

Thomson, J. 1864. Systema cerambycidarum ou exposé de tous les genres compris dans la famille des cérambycidaes et familles limitrophes. Mémories de la Société Royale des Sciences de Liège 19: 1540 .

White, A . 1855. Catalogue of the coleopterous insects in the collection of the British Museum. Longicornia 2. London, British Museum, 8: 175-412.

Zajciw, D. 1967. Novos longicórneos neotrópicos XII (Col., Cerambycidae, Cerambycinae). Memórias do Instituto Osvaldo Cruz 65 (2): 199-204. 